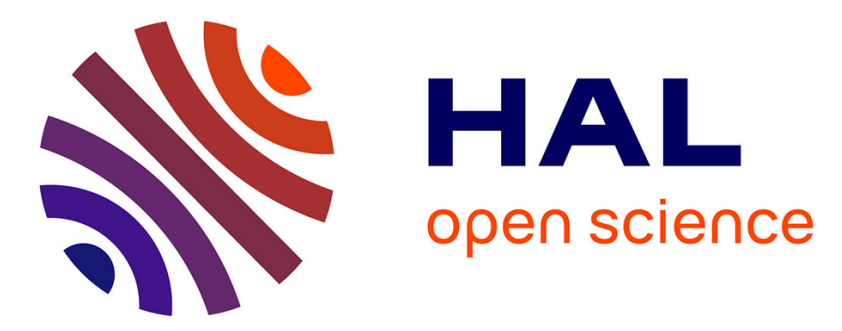

\title{
Stratigraphy of the Paleocene continental sedimentary succession of the northern Pyrenean basin (Corbières, southern France) using $\delta 13$ Corg isotopes
}

A Maufrangeas, S Leleu, C Loisy, Pierrick Roperch, D Jolley, C Vinciguerra, O Nguyen-Thuyet

\section{To cite this version:}

A Maufrangeas, S Leleu, C Loisy, Pierrick Roperch, D Jolley, et al.. Stratigraphy of the Paleocene continental sedimentary succession of the northern Pyrenean basin (Corbières, southern France) using $\delta 13$ Corg isotopes. Journal of the Geological Society, 2020, 177 (4), pp.752-765. 10.1144/jgs2019-084 . insu-03018792

\section{HAL Id: insu-03018792 \\ https://hal-insu.archives-ouvertes.fr/insu-03018792}

Submitted on 23 Nov 2020

HAL is a multi-disciplinary open access archive for the deposit and dissemination of scientific research documents, whether they are published or not. The documents may come from teaching and research institutions in France or abroad, or from public or private research centers.
L'archive ouverte pluridisciplinaire HAL, est destinée au dépôt et à la diffusion de documents scientifiques de niveau recherche, publiés ou non, émanant des établissements d'enseignement et de recherche français ou étrangers, des laboratoires publics ou privés. 


\title{
Article publié dans le Journal of the Geological Society
}

https://doi.org/10.1144/jgs2019-084 | Vol. 177 | 2020 | pp. 752-765

\section{Stratigraphy of the Paleocene continental sedimentary succession of the northern Pyrenean basin (Corbières, southern France) using $\delta^{13} C_{\text {org }}$ isotopes}

\author{
A. Maufrangeas ${ }^{1 *}$, S. Leleu ${ }^{1}$, C. Loisy ${ }^{1}$, P. Roperch ${ }^{2}$, D. Jolley ${ }^{3}$, C. \\ Vinciguerra ${ }^{1}$ and O. Nguyen-Thuyet ${ }^{1}$ \\ ${ }^{1}$ Bordeaux INP/Université Bordeaux Montaigne, G\&E, EA 4592, 1 Allée Daguin, F-33600 \\ Pessac, France \\ ${ }^{2}$ Géosciences Rennes, Centre National de la Recherche Scientifique (CNRS), France \\ ${ }^{3}$ University of Aberdeen, School of Geosciences, King's College, Aberdeen AB24 3FX, UK
}

\section{Abstract}

Continental-dominated successions are often poorly constrained stratigraphically due to a lack of robust biostratigraphic markers. This study provides the first dataset of $\delta{ }_{13} \mathrm{C}_{\text {org }}$ together with magnetostratigraphic and biostratigraphic data from a thick continental-dominated succession at Lairière (northern Pyrenees, France). This section encompasses the latest Cretaceous up to the Paleocene-Eocene Thermal Maximum interval and is characterized by fluvial deposits, occasionally intercalated with continental carbonates, lacustrine deltaic deposits and shallow marine sediments. This work identifies $\delta_{13} C_{\text {org }}$ events and assigns them to global $\delta_{13} \mathrm{C}$ geochemical events defined in Pyrenean and Tethyan marine successions, in which the stage boundaries are well calibrated. As the isotopic measurements are performed on dispersed organic matter in sedimentary rocks with a low organic content, we propose that analyses of the signal should take into consideration the depositional environment because variations in the organic matter content might affect the signal. We establish a high-resolution chronostratigraphy in terrestrial Paleocene deposits in the NE Pyrenean zone, recognize a late Selandian interval and define the Paleocene-Eocene Thermal Maximum event. 
Supplementary material: Palaeomagnetic results, geochemistry details and palynological analysis are available at https://doi-

org.insu.bib.cnrs.fr/10.6084/m9.figshare.c.4871214

\section{Introduction}

Paleocene strata over a large area of southern France to northeastern Spain were deposited in almost exclusively terrestrial environments. Our current understanding of Paleocene stratigraphy in the northern Pyrenean foreland is based on correlation with the marine deposits located west of the Corbières area known as the 'Petites Pyrénées'. These are relatively well calibrated by biostratigraphy (Gruas-Cavagnetto et al. 1992; Tambareau et al. 1995), whereas the terrestrial deposits, mainly of alluvial and lacustrine origin, are less constrained due to a lack of biostratigraphic markers. Nevertheless, stratigraphic correlations have been attempted based on charophytes (Marty and Meyer 2006), ostracods and palynomorphs (Gruas-Cavagnetto et al. 1992) and marine incursions (Lepicard et al. 1985; Gruas-Cavagnetto et al. 1992; Tambareau et al. 1995, 1997).

Isotopic methods can accurately and precisely date stratigraphic records for the Paleocene interval. Isotopic stratigraphy using ${ }^{13} \mathrm{C}$ variations within and between marine and terrestrial sedimentary settings is a worldwide correlation tool (Koch et al.1992; Cojan et al. 2003; Magioncalda et al. 2004). The Early Paleogene is considered as a warm interval and was punctuated by a few hyperthermal events related to massive and brief episodes of greenhouse gas emissions to the atmosphere, the most pronounced event being the Paleocene-Eocene Thermal Maximum (PETM; Dickens et al. 1995; McInerney and Wing 2011). Many carbon excursions have been identified and defined in reference marine sections in the Paleocene, e.g. the Pacific Ocean Drilling Program Site 1209 (Westerhold et al. 2011) and at Gubbio, Italy (Coccioni et al.2012). Their recognition in terrestrial environments could allow the definition of an accurate stratigraphy in poorly dated successions.

We present here a new $\delta{ }^{13} \mathrm{C}_{\text {org }}$ record for 131 samples spanning the Paleocene succession from an almost $500 \mathrm{~m}$ thick section at a location in the Corbières area (Lairière, southern France; Fig. 1a). It is complemented by a magnetostratigraphic study performed on 268 samples with the identification of biostratigraphic markers. Our aim is to refine the Paleocene stratigraphy in the north Pyrenean domain by establishing regional and global correlations based on $\delta^{13} \mathrm{C}_{\text {org }}$ from the latest Cretaceous to the earliest Eocene. 

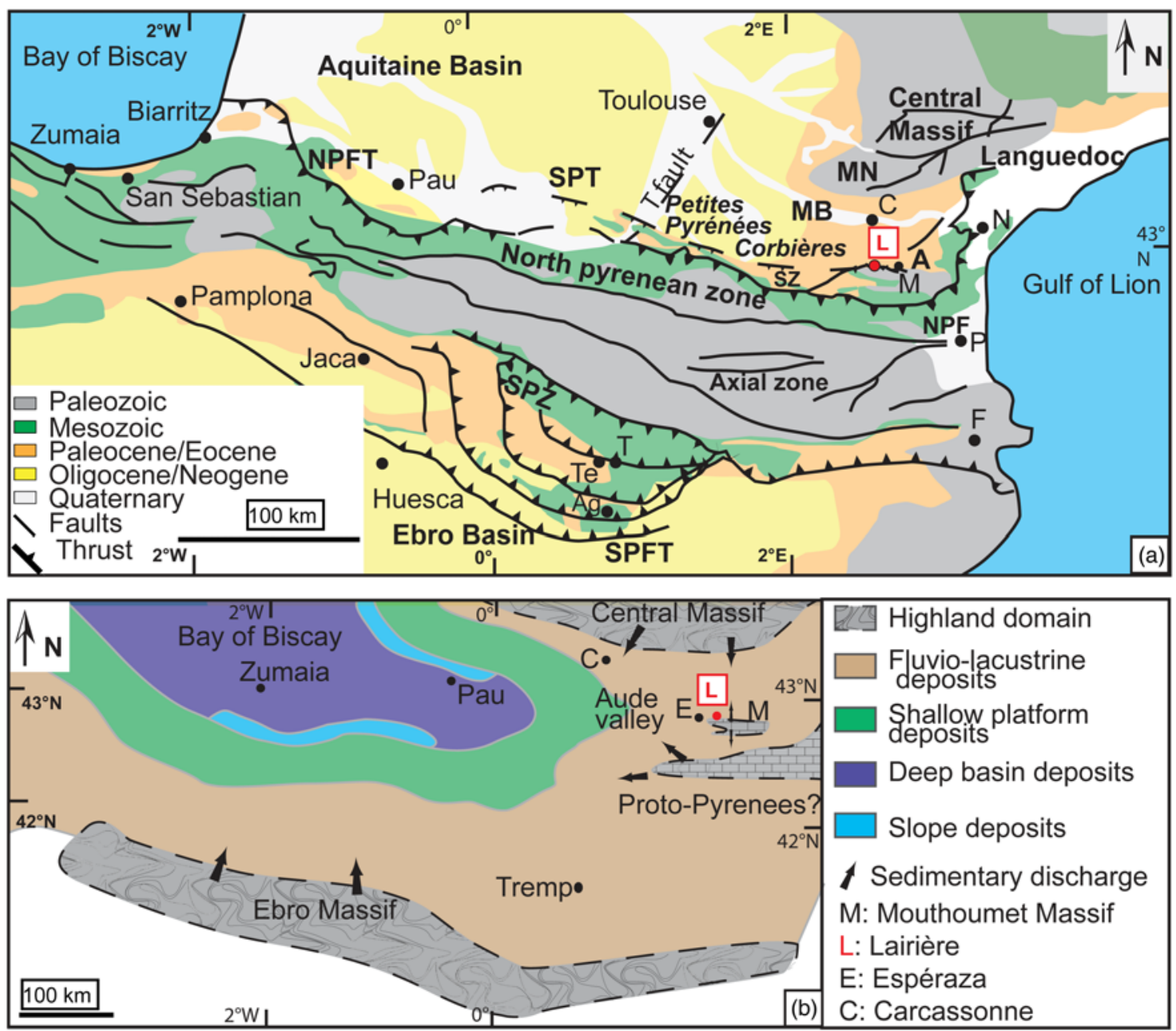

Figure 1. Location of the study area. (a) Detailed geological map (modified from the BRGM 1:1000 000 geological map; Chantraine et al.1996). A, Albas; AG, Ager; C, Carcassonne; F, Figueras; M, Mouthoumet; MB, Minervois basin; MN, Montagne Noire; N, Narbonne; NPF, north Pyrenean fault; NPFT, North Pyrenean frontal thrust; P, Perpignan; SPFT, south Pyrenean frontal thrust; SPT, Sub-Pyrenean thrust; SPZ, south Pyrenean zone; SZ, Sub-Pyrenean zone; T, Tremp; Te, Tendruy; Tfault, Toulouse fault. (b) Palaeogeography of the early Danian (modified from Plaziat 1981; Baceta et al. 2005).

\section{Geological setting}

The Paleocene is a peculiar epoch in Earth history because it begins with major events such as asteroid impacts, the largest and best known being the Chicxulub impact on the Yucatan peninsula, Mexico, which defines the Cretaceous-Paleogene (K-Pg) boundary (e.g. Schulte et al. 2010). This and other impacts (e.g. the Boltysh impact, Ukraine; Kelley and Gurov 2002; Jolley et al. 2010) exercised major controls on the composition of the Paleocene atmosphere, which was further controlled by forcing from the emplacement of two large igneous provinces: the Deccan Traps in India (66.25 Ma; Renne et al. 2015) 
and the North Atlantic Igneous Province starting in the Late Danian and lasting up to earliest Eocene times (Knox and Morton 1988; Watson et al. 2017). These major events were responsible for massive, global and rapid floral and faunal extinctions and turnover (Alvarez et al. 1980; Schulte et al. 2010; Renne et al. 2013) and are important parameters controlling the sedimentary records and their $\delta^{13} \mathrm{C}$ variations.

\section{Pyrenean orogeny}

The Pyrenean orogen resulted from the collision between the Iberian and European plates (Olivet 1996), forming an east-west-trending topographic structure (Fig. 1a). After an initial convergence thought to be Santonian in age (Vergés et al. 2002), the first compressional phase of the Pyrenean orogeny occurred between the Campanian and Maastrichtian and was followed by an interval of tectonic quiescence lasting from the

latest Maastrichtian to late Paleocene (Christophoul et al.2003; Pujalte et al.2014; Ford et al. 2016). Despite the subsidence rate slowing down across the orogeny (e.g. Ford et al.2016), important thickness variations have been reported in the northern foreland during the Paleocene successions (Plaziat 1984; Tambareau et al.1995). Subsequently, the main orogenic phase occurred from the Ypresian to Early Miocene (Vergés et al. 2002; Bilotte and Canerot 2006; Filleaudeau et al. 2012; Ford et al. 2016), during which time the main thrusts were activated and deformation moved to the more external parts of both forelands.

\section{Paleocene sedimentology of the Pyrenean domain}

During the Paleocene, the Pyrenean domain was connected to the Atlantic Ocean to the west, towards the Bay of Biscay (Fig. 1b). This formed an east-west marine gulf (Plaziat 1981) where carbonate platforms developed in shallower zones (Plaziat 1981, 1984; Pujalte et al. 2014) while deep marine facies of pelagic carbonates and turbidites (Gély and Sztràkos 2000; Baceta et al. 2005) were deposited in the western part of the Pyrenean realm, forming a V-shaped basin (Fig. 1b). Laterally, in the continental domain close to the carbonate platform, and mainly to the east, continental deposits were dominated by red mudstones intercalated with conglomeratic and sandy fluvial channel fills and subordinate continental carbonates (Plaziat 1981, 1984).

The sea-level in the Pyrenean domain was at its lowest during Danian times when the shoreline was located to the west of Toulouse (Fig. 1a). Three marine transgressions 
were later reported in the Central Pyrenees (Tambareau et al. 1995). Only two reached the easternmost terrestrial domain (Corbières area), in which thin beds of shallow marine carbonates were intercalated in the fluvial red beds. The sea-level rose again during the Early Ypresian and persisted over time, as indicated by the thick carbonate platform deposits known regionally as the Ilerdian Limestones or Ilerdian Marine Unit (IMU) (Fig. 2).

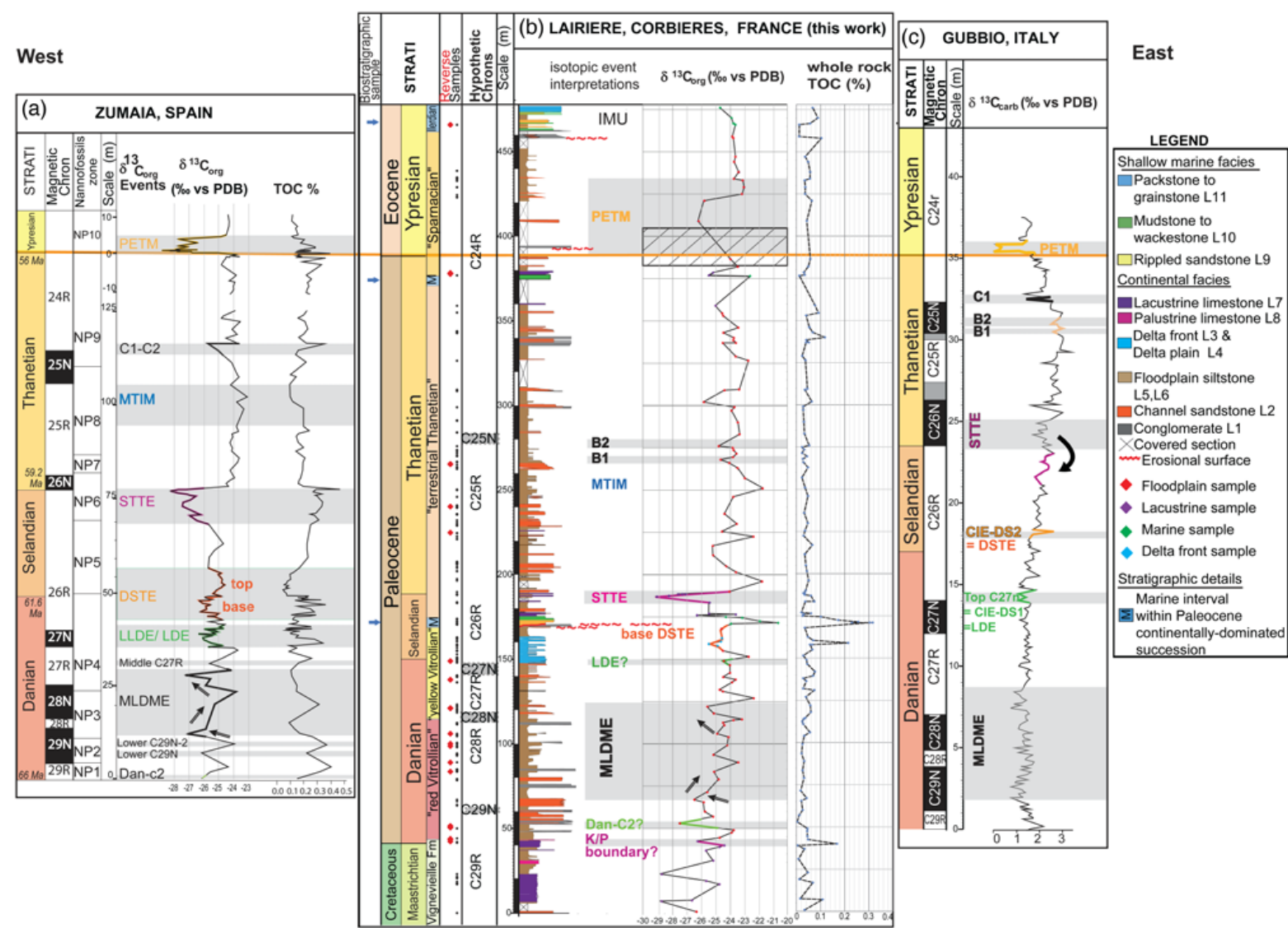

Figure 2. Lairière section (this work) correlated with the high-resolution carbon isotope dataset and magnetostratigraphic polarity chrons of two main marine sections calibrated with biostratigraphy across the entire Paleocene epoch from the Atlantic to the Tethys domains. (a) Zumaïa reference section; dataset from Storme (2013). (b) Lairière dataset (this work) showing $\delta^{13} \mathrm{C}_{\text {org }}$ plotted against the lithofacies and total organic carbon (TOC) content. It is assumed that a TOC $>0.07 \%$ is necessary for a reliable $\delta{ }_{13} \mathrm{C}_{\text {org }}$ measurement. The magnetic samples have been plotted: the black squares show the measured samples and the red squares show the depositional reverse remanent signal (see Supplementary material 2); arrows show the location of the biostratigraphic samples (see Supplementary material 3). (c) Gubbio reference section; dataset from Coccioni et al. (2012). PETM, Palaeocene Eocene Thermel Maximum; MTIM, Mid-Thanetian Isotope Maximum; LLDE, Large Latest Danian Event; DSTE, DanianSelandien Transition Event; STTE, Selandien Thanetian Transition Event; CIE, Carbon isotope excursion. 


\section{Chronostratigraphy}

The base of the Paleocene (i.e. the K-Pg boundary) is defined at the Global Standard Stratotype Section and Point of Tunisia (Dupuis et al. 2001; Molina et al. 2006) and lies within magnetochron C29r. The K-Pg boundary is marked by an iridium and osmium anomaly (Alvarez et al. 1980) and is characterized by a $0.5-4 \%$ negative shift in the carbon isotope records in various carbonate materials and organic matter from both marine and continental sediments (Keller and Lindinger 1989; Schmitz et al. 1992; Arens and Jahren 2000). It corresponds to a rapid global turnover of life on Earth (Schulte et al. 2010).

The current international chronostratigraphic chart (Cohen et al. 2013) defines three stages in the Paleocene (Vandenberghe et al.2012): the Danian (66-61.6 Ma), the Selandian (61.6-59.2 Ma) and the Thanetian (59.2-56 Ma). The Danian-Selandian (61.6 $\mathrm{Ma}$ ) and Selandian-Thanetian (59.2 Ma) boundaries are defined in the Zumaia section in the western Pyrenees (Dinarès-Turell et al. 2007; Schmitz et al. 2011) and correspond to biostratigraphic and magnetostratigraphic changes, respectively. The Danian-Selandian corresponds to the NP4-NP5 limit and the Selandian-Thanetian corresponds to the C26r-C26n limit (Schmitz et al. 2011).

The Danian-Selandian boundary is also linked to an important increase in the proportion of shale at Zumaia and evidence of sea-level fall can be used to place this limit (Schmitz et al. 2011). The Selandian-Thanetian boundary is not associated with an abrupt shift in facies, but corresponds to a transgressive phase in the southern Pyrenees (Pujalte et al. 2014). The best marker of the base of the Thanetian is C26r-C26n, but the Mid-Paleocene Biotic Event can also be used (Schmitz et al. 2011).

The Paleocene-Eocene boundary has been defined in the Dababiya section in Egypt on geochemical arguments. It corresponds to the onset of a pronounced (2.5-6\%0) negative carbon isotope excursion (CIE) within magnetochron C24r (Aubry et al.2007). This negative CIE is coeval with the PETM, a major global warming event that lasted for c. 170 ka (Röhl et al. 2007). It has been recognized in both marine and continental successions (Koch et al.1992; Magioncalda et al. 2004) and coincides with major palaeontological global events (Scheibner et al. 2005; Scheibner and Speijer 2008). 


\section{Lithostratigraphy and biostratigraphy in the Corbières region}

Numerous regional stages and lithostratigraphic units persist from the earliest geological investigations in the northern continental Pyrenean domain (Villatte 1962; Freytet 1970; Tambareau 1972; Plaziat 1966,1984). The terms Rognacian and Vitrollian were used to describe fine-grained continental facies, equivalent to the Spanish Garumnian facies; Sparnacian was defined in the Paris basin for gypsiferous fine-grained sediments and used in the Corbières area by Plaziat $(1966,1981,1984)$, but brings confusion about the age because it is older in the Corbières area. These regional stages are used in various publications and geological maps from the BRGM. A recent overview of the north Pyrenean foreland basin compiled the various lithological formations and ages and suggested a new stratigraphic scheme (Ford et al.2016). A combination of the different schemes is synthetized in Figure $2 \mathrm{~b}$.

The K-Pg boundary is not well localized in most of the regional sections and is supposed to lie within the upper part of thick continental carbonate beds (the Vignevieille Limestone Formation) in relation to the occurrence of Maastrichtian and Danian charophyta key taxa (Marty and Meyer 2006, in the Espéraza location) and dinosaur eggshells v. bird eggshells (Freytet 1970; Gruas-Cavagnetto et al. 1992; Berger et al. 1997; Fondevilla et al. 2016).

The Danian and Selandian stages are known regionally as Vitrollian or Dano-Montian (Villatte 1962; Plaziat 1984; Fig. 2). The exact position of the Danian-Selandian boundary is not known, however, because it is difficult to delineate in terrestrial successions and because the international Selandian stage was not introduced officially until 2007 (Schmitz et al. 2011). The most recent publications related to the Paleocene Corbières stratigraphy predate the creation of the Selandian stage by more than 10 years. In the last 20 years, although studies in the Spanish Pyrenees seem to agree on the lack of Selandian deposits (Robador 2005; Pujalte et al. 2014), many publications about the northern Pyrenean domain debate whether marine Selandian deposits are preserved (Peybernes et al. 2001; Canérot and Rey 2008). Our work suggests that the late Selandian transgressive facies are preserved overlying a major Early Selandian hiatus (Fig. 2).

A Thanetian age has been attributed to thin shallow marine beds intercalated within the terrestrial facies in the Corbières area by correlation with miliolid limestones containing Glomalveolina primaeva (SBZ3) and Glomalveolina levis (SBZ4) in the western 
Petites Pyrénées area (Fig. 1a) (Plaziat 1984; Tambareau et al. 1995). The PaleoceneEocene (P-E) boundary was formerly defined at the base of the IMU by the appearance of the benthic foram Alveolina vredenburgi (SBZ5) (ex. Alveolina cucumiformis), a marine microfauna belonging to the regional Ilerdian stage (Plaziat 1975; Serra-Kiel 1998; Pujalte 2009). However, the onset of the PETM negative CIE has recently been recorded below the IMU in sections from the Spanish Pyrenees (Domingo et al. 2009; Minelli et al. 2013; Pujalte et al. 2015) and from the nearby Albas section (Corbières; Yans et al. 2014, Fig. 3).

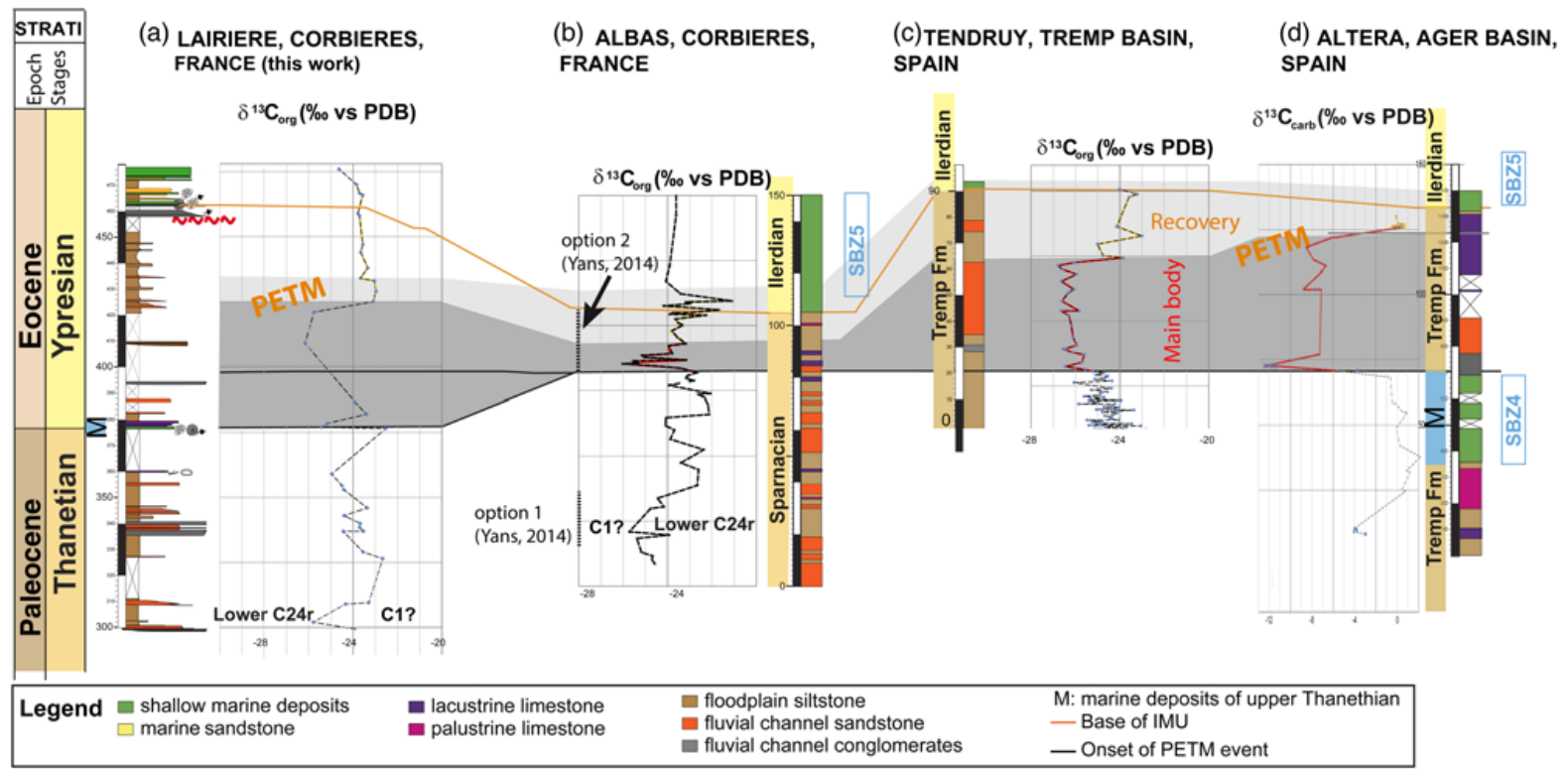

Figure 3. High-resolution correlation scheme of the Paleocene-Eocene Thermal Maximum interval in the Pyrenean area using the $\delta{ }^{13} \mathrm{C}_{\text {orgas }}$ a marker. (a) interpreted Lairière dataset (this work). (b) Albas section (Corbières, France) from Yans et al. (2014) and attempt at correlation. (c) Tendruy section from Domingo et al. (2009). (d) Ager section from Minelli et al. (2013). PETM, Palaeocene Eocene Thermal Maximum; Fm, Formation.

\section{Carbon isotope events as Paleocene stratigraphic markers}

CIEs have been used as chemostratigraphic markers for a few decades because both marine and terrestrial biota are considered to record isotopic variations isochronous at the global scale (Koch et al.1992, 2003; Cojan 2000; Magioncalda et al. 2004; Domingo et al. 2009; Storme et al. 2014; Yans et al. 2014). Marine and terrestrial sedimentary successions can therefore be correlated once they have been calibrated throughout the integrated stratigraphy on key reference sections. In terrestrial environments, carbon isotope analyses are often undertaken on soil nodules, lacustrine or palustrine carbonates (Koch 1998; Bowen et al. 2001; Schmitz et 
al.2011; Cojan et al. 2003). They are less often performed on organic matter dispersed in the sediments (Magioncalda et al. 2004; Domingo et al. 2009; Storme 2013). Comparing the response between the $\delta^{13} \mathrm{C}_{\text {org }}$ and $\delta^{13} \mathrm{C}_{\text {carb }}$ signals, it seems that, despite differences in absolute values, their tendencies and variations through time are similar and can be compared (e.g. Magioncalda et al. 2004). We chose to perform $\delta^{13} \mathrm{C}_{\text {org }}$ analyses on our samples to obtain more regularly spaced samples and to avoid any bias due to diagenetic carbonate precipitation, which may alter the signal.

Paleocene and Eocene floras only contain C3 photosynthetic vegetation (Cerling and Quade 1993; Jacobs et al. 1999) with negative $\delta^{13} \mathrm{C}$ organic values, in contrast with C4 plants, which yield much more positive $\delta^{13} \mathrm{C}$ signatures. This avoids problems in the interpretation of the organic $\delta^{13} \mathrm{C}$ curves and shifts related to the variation in amounts of C3 and C4 plant components in the studied sediments (Lopez and Cojan 2000).

A few isotopic events (shifts, peaks and excursions) and trends during the Paleocene and Eocene can be used worldwide as stratigraphic markers (Koch et al. 1992; Zachos 2001; Zachos et al. 2008; Westerhold et al. 2011). Some of these events are brief, with negative CIEs that correspond to drastic environmental changes related to hyperthermal events and have therefore been studied intensively: the K-Pg boundary; the Dan-C2; the Latest Danian Event (LDE), also called Top Chron C27 or CIE-DS1 (Arenillas et al. 2008; Bornemann et al.2009; Westerhold et al.2011; Coccioni et al.2012); the Selandian-Thanetian Transition Event (STTE), including the Mid-Paleocene Benthic Extinction event, also known as the Early Late Paleocene Event (Petrizzo 2005; Bernaola et al. 2007; Westerhold et al.2011); and the PETM (see Aubry et al.2007 and references cited within).

Other notable, but less studied, events of the Paleocene recognized in Gubbio (Fig. 2, Coccioni et al. 2012) and Zumaia (Storme 2013; Fig.3), including: the Lower C29n, the Mid- to Early Danian Multiple Event (MLDME, Storme 2013); the Mid-C27r events; the Danian-Selandian Transition Event (DSTE); and, in the Thanetian, the Mid-Thanetian Isotope Maximum (MTIM) located within the upper part of C25r and B1, B2, C1, C2 (Fig. 2).

\section{Materials and methods}


We collected samples from the Paleocene Lairière section and carried out the following measurements and analyses: $\delta{ }^{13} \mathrm{C}_{\mathrm{org}}$; calcimetry and total organic carbon (TOC) measurements; magnetostratigraphy; and some thin sections.

\section{Fieldwork and sample collection}

At Lairière, the $476 \mathrm{~m}$ thick succession, tilted at $20-30^{\circ}$ dip, exhibits an almost continuous exposure from the latest Cretaceous to the Early Eocene, thus encompassing the Paleocene interval. It was logged in detail to determine the sedimentary facies and to collect samples for petrographic characterization, isotopic measurements of $\delta{ }^{13} \mathrm{C}_{\mathrm{org}}$, TOC, magnetostratigraphic studies, as well as for biostratigraphic and palynological marker recognition.

\section{$\delta_{13} \mathrm{C}_{\text {org }}$, calcimetry and TOC measurements}

A total of 122 samples were collected from siltstone, sandstone $(70 \%)$ and carbonate (10\% in marine deposits and $20 \%$ in continental carbonates rocks) sediments in the Lairière section, most of which are continental deposits (Fig. 2). The average spacing between samples was $3.5 \mathrm{~m}$, but some intervals could not be sampled due to vegetation cover. Sample preparation before the isotopic measurements followed a protocol described in Magioncalda et al. (2004) and Storme, (2013): First, the bulk samples were dried and cleaned to avoid contamination from present day organic matter; they were then ground into a powder and treated with $25 \% \mathrm{HCl}$ solution for decarbonation. The acid was then neutralized by multiple centrifugations (seven to 15 times) with distilled water until a neutral sediment was obtained. The residues were dried at $30^{\circ} \mathrm{C}$ and then once again ground into powder.

The TOC was measured on decarbonated samples with a C-S Horiba Emia $820 \mathrm{~V}$ elemental analyser at the BRGM laboratory (Orléans, France). The $\delta^{13} C_{\text {org }}$ content of each sample was measured twice using a Thermo Flash EA 112 mass spectrometer coupled to a Thermo Finnigan Delta V plus continuous flow isotope ratio mass spectrometer in the BRGM laboratory. Each sample was weighed into tin capsules and combusted at $900^{\circ} \mathrm{C}$ under oxygen. The isotopic ratios were determined using a calibration based on the international standards LSVEC (-46.5\%o V-PDB), IAEA-C5 (-25.5\% V-PDB), IAEA-C6 $(-10.6 \%$ V-PDB $)$, IAEA-C1 $(+2.4 \%$ V-PDB $)$ and an in-house standard close to the samples (PROLABO RP -26.6\% PDB). The accuracy was tested by introducing the 
international standards USGS $40(-26.25 \pm 0.09 \%$ V-PDB) and IAEA-C5 every fifth

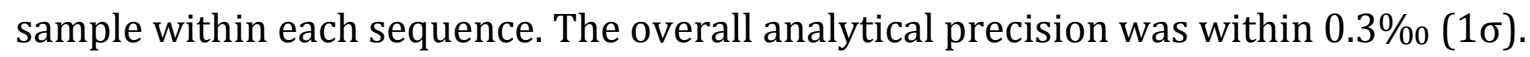

\section{Magnetostratigraphy}

A total of 268 samples were collected along the Lairière section using a gasolinepowered drill and were oriented with magnetic and sun compasses. Each $2.54 \mathrm{~cm}$ diameter core provided two or three standard $22 \mathrm{~mm}$ specimens. The natural remanent magnetization (NRM) was measured with a $2 \mathrm{G}$ cryogenic magnetometer in a shielded room at the palaeomagnetic laboratory of Géosciences Rennes. Thermal demagnetization was carried out in an MMTD furnace. Isothermal remanent magnetization (IRM) and thermal demagnetization of the IRM were carried out to constrain the remanent magnetic carriers. Low-temperature experiments with an MPMS-XL5 were carried out at the Institut de Physique du Globe de Paris (Paris, France).

\section{Results}

\section{Sedimentology of Lairière section}

Eleven lithofacies are recognized in the Lairière section and are described and interpreted in Table 1. The lithofacies are grouped into five depositional environments: fluvial channel (L1 and L2, Table 1); lacustrine delta (L3, L4 and L5); floodplain (L5 and L6); continental carbonates (L7 and L8); and shallow marine (L9, L10 and L11).

The fluvial channel environment consists of cross-bedded conglomerates and finegrained sandstones (L1 and L2, Table 1). The fluvial sand bodies are very thin $(<3 \mathrm{~m})$ and present erosive channel fills (L2a and L2b). The grain size is generally fine, wellsorted and shows fining-upwards sequences that pass laterally to channel wings (L2c). The tops of the sand bodies often show pedogenic features, such as root traces, mottling and bioturbation. Two types of fluvial channel sand bodies are defined, corresponding to the L2a and L2b sub-lithofacies (Table 1). L2a shows large compound point bar sand bodies deposited by high-sinuosity rivers (L2a). These channels occasionally contain some conglomeratic deposits at the base of the channel fills. They form lenses up to 2.50 $\mathrm{m}$ thick and with up to $300 \mathrm{~m}$ of lateral extent. L2b are smaller channel sand bodies $(<50$ 
$\mathrm{m}$ of lateral extent) that lie on the same stratigraphic horizons linked by overbank deposits. L2b therefore records an anastomosed ('fixed') system (Gibling 2006).

The geometry, grain size and sorting of the fluvial sand bodies as well as their pedogenic features relative to the high water table suggest very low energy sinuous fluvial channels (Gibling 2006; Miall 2006; Bridge 2007). This fine-grained fluvial system is punctuated by conglomeratic beds (L1), the size of which varies greatly from a few metres to a kilometre-scale lateral extent. The conglomerates contain pebbles that mainly originate from the Mesozoic regional cover (Table 1; Plaziat 1981,1984) and their channel geometry suggests high-capacity streams and steeper slopes lateral to the fine-grained fluvial system (Plaziat 1984, Miall 2006). Conglomeratic and sandstone channels are intercalated in the floodplain, which is the dominant facies (L5 and subordinate L6 and L2c) in the Lairière section (>60\%). The channel bodies constitute $<20 \%$ of the total volume of strata.

A lacustrine deltaic system (L3 and L4, Table 1; Pollard et al. 1982; Tye and Coleman 1989) was recognized from an analysis based on the architecture: prograding clinoforms (e.g. Rich 1951) of heterolithic sandstones (L4) show couplets of siltstones and fine-grained sandstone lenses downlapping onto large low-angle sand bodies (L3) formed by compound channel fills in which no internal structure, except erosional surfaces, is preserved.

The floodplain depositional environment mainly consists of siltstones and claystones (L5), which present abundant pedogenic features such as root traces and carbonate glaebules (L5a and L5b), the latter indicating a contrasting semi-arid seasonal climate with a relatively high water table allowing the development of vegetation (Freytet and Plaziat 1982). The floodplain deposits contain subordinate Microcodium-rich beds (L6) and thin beds of fine-grained sandstones representing the channel overbanks (L2c). The Microcodium-rich beds are made of carbonate Microcodium crystals and a dark red clay matrix and are always located close to the channel bodies or at the top of the channel-fill sequences. As no grains are preserved, the host sediments were transformed by these terrestrial processes (Freytet and Plaziat 1982; Wright et al.1995; McConnaughey and Whelan 1997).

The depositional environment of the continental carbonates consists of grey or dark lacustrine carbonate mudstone (L7) (occasionally containing shell fragments, charophyta and ostracods) and palustrine mottled carbonate mudstone (L8) 
(occasionally showing root traces and recrystallization). They form either laterally extensive beds or beds of limited extension lateral to some pedogenic horizons.

Two marine occurrences are reported (Fig. 2) before the emplacement of the regional IMU. The first marine occurrence is $5 \mathrm{~m}$ thick (at 170-175 $\mathrm{m}$ in the logged section). It is composed of rippled sandstones rich in coal debris and Miliolidae (L9), overlain by carbonate mudstone to wackestone beds containing ostracods, peloids, mollusc shells, frequent Miliolidae as well as benthic and very rare planktonic forams and some quartzitic grains (L10). Eight samples were collected for biostratigraphic analyses: three for foram analysis and five to determine the palynofacies (see Supplementary material 4). The poor preservation and content did not allow the determination of a strict age, but dinocysts, pollen and spores constrain this interval (171-175 m) to a Selandian and a basal Thanetian stage (see Supplementary material 4). The state of preservation did not allow clear recognition of the foram taxa. The second marine bed in the Lairière section is only $10 \mathrm{~cm}$ thick (at $376 \mathrm{~m}$; Fig. 2) and is composed of marine carbonate packstone with numerous peloids, no planktonic but a few benthic forams, including abundant Miliolidae and rare Alveolina. This bed was interpreted in previous studies to correlate with marine carbonates containing Alveolina levis (Plaziat 1984; Tambareau et al. 1995) further west in the northern Pyrenean foreland basin, which suggests a Thanetian age; this is consistent with our observations and interpretation. The base of the IMU in the upper part of the section is well marked by dominant packstone to grainstone (L11) and subordinate mudstone to wackestone (L10).

\section{TOC and $\delta{ }_{13} C_{o r g}$ record in the Lairière section}

The TOC values (Fig. 2) range from 0.003 to $0.320 \%$ with a mean of $0.050 \%$. The organic matter content is higher in the sandstone bars, continental carbonates and fluvial rocks than in the red siltstone samples. The mean $\delta{ }^{13} \mathrm{C}_{\text {org }}$ is $-24.5 \%$, with values ranging from -19.6 to $-29.1 \%$ o. This shows successive CIEs, trends and smaller peaks (Fig. 2; Supplementary material 1). CIEs exceeding 2\%o in amplitude are the most striking events, with some reaching $-5.5 \%$. Petrographic analysis of organic matter was attempted on five samples in the L7, L9 and L10 facies to check the state of preservation, but no satisfactory image could be obtained because the organic fragments were far too small. 


\section{Magnetostratigraphy}

The limestone beds sampled below the K-Pg boundary have a very low NRM (geometric mean $\left.0.015 \mathrm{~mA} \mathrm{~m}^{-1}\right)$ and diamagnetic susceptibility. The NRM intensity $\left(0.76 \mathrm{~mA} \mathrm{~m}^{-1}\right)$ and the magnetic susceptibility $\left(3.7 \times 10^{-5} \mathrm{~m}^{3} \mathrm{~kg}^{-1}\right)$ are slightly higher in the Paleogene siltstone and claystone. During thermal demagnetization, the intensity of the NRM was halved at $130^{\circ} \mathrm{C}$ for $>70 \%$ of the samples, with $50 \%$ of samples losing $70 \%$ of their initial NRM.

The direction of the low-temperature component of the magnetization determined in the temperature interval $80-210^{\circ} \mathrm{C}$ is well defined $\left(D=359.4^{\circ}, I=56.9^{\circ}, \alpha_{95}=1.1^{\circ}, k=96, N=175\right)$ and is close to the present day field at the site location $\left(D=0.7^{\circ}, I=58.5^{\circ}\right)$ using in situ coordinates. After correction for tilt, this low-temperature component $\left(D=350.7^{\circ}, I=18.9^{\circ}\right)$ is far from the expected Paleocene direction for southern France (Supplementary material 2, Fig. A). The IRM acquisition data show that the magnetic mineralogy is dominated by high-coercivity minerals (such as goethite and hematite), whereas magnetite was only identified in a few samples (Supplementary material 2, Figure A). Thermal demagnetization of the IRM and lowtemperature measurements with an MPMS XL5 magnetometer confirmed that goethite is an important magnetic phase in many samples (Supplementary material 2, Fig. A). After thermal cleaning at $210^{\circ} \mathrm{C}$, most of the samples have palaeomagnetic directions with a negative inclination and are far from the present day field. Unfortunately, many samples provided scattered demagnetization diagrams and we are able to assign a magnetic polarity to only 47 of 268 samples, all showing a reverse polarity (Supplementary material 2, Figs B and C). For the other 221 samples, the depositional magnetization cannot be deciphered, so no data is available (see Supplementary material 2 and 3 ).

The Earth's magnetic field was mainly of reverse polarity from the Paleocene to the Early Eocene, with short-lived normal chrons, except for chrons c29n and c28n, which partly explains the lack of normal polarity samples in the dataset. Several hiatuses were recognized in the field and normal polarity chrons may not be recorded at all. However, the available results are poorly distributed throughout the section (Supplementary material 2, Fig. C). Thus we cannot discard the possibility that some normal polarity intervals were not sampled. The large goethite content and the poor magnetic record also indicate chemical alteration, so the samples with reverse polarity may have a 
chemical remanent magnetization acquired during the roughly 10 myr period of mainly reverse polarity (63.5-54 Ma) rather than a detrital magnetization acquired during or shortly after deposition. We considered the 47 reverse polarity samples from this dataset (in red on Fig. 2) to compare the Lairière isotopic record with the global isotopic events in the calibrated sections. The correlation of robust inverse polarity and isotopic events that are known to lie within the inverse chron are considered as the most robust interpretation of our dataset (Fig. 2). The presented potential chrons in Figure 2 are speculative and cannot be taken for granted.

\section{Discussion}

\section{High-resolution stratigraphy within Paleocene continental deposits using $\delta_{13} C_{o r g}$ variations and reverse polarity records}

We compare a c. $350 \mathrm{~m}$ Paleocene sedimentary succession deposited in mainly terrestrial environments at Lairière, France with two marine reference sections of $c .150$ $\mathrm{m}$ at Zumaia, Spain (Dinarès-Turell et al.2007; Schmitz et al.2011; Storme 2013; Manners et al. 2013; Dunkley Jones et al.2018) and $45 \mathrm{~m}$ at Gubbio, Italy (Coccioni et al. 2012) on which $\delta^{13} \mathrm{C}_{\text {org }}$ and $\delta^{13} \mathrm{C}_{\text {carb }}$ have been measured, respectively. The chronostratigraphy of the successions at Zumaia and Gubbio are well calibrated by magnetostratigraphy and biostratigraphy. We propose a correlation of geochemical events between these sections to allocate stratigraphic ages for the continental Lairière succession (Fig. 2).

\section{From the K-Pg boundary to the Late Danian}

At the base of the Lairière section, one negative CIE of $-1.9 \%$ occurs at $42.5 \mathrm{~m}$ at the top of the second continental carbonate bed of the Vignevielle Limestone Formation and is associated with a sudden increase in the TOC content. This excursion is probably the $\mathrm{K}-$ Pg boundary because it is consistent with the biostratigraphic data within the uppermost regional Vignevieille Limestone Formation (e.g. in the Albas section $20 \mathrm{~km}$ to the east; Freytet 1970; Berger et al. 1997; Marty and Meyer 2006). The K-Pg boundary shows a negative shift of -2 to $-3 \%$ in sections such as at Bidart (Pays Basque, France) (Bonté et al.1984; Minoletti et al. 2004) and Tunisia (El Kef; Keller and Lindinger 1989; Molina et al. 2006). A robust magnetic signal at $42.5 \mathrm{~m}$ has an inverse polarity, which could correspond to chron C29r. The two main negative excursions below the K- 
Pg boundary might be within chron C29r because a recent magnetostratigraphic study in the Aude valley (c. $25 \mathrm{~km} \mathrm{SW}$ of Lairière) suggests that a major hiatus occurred in the area between chron C31n and the base of chron C29r (Fondevilla et al. 2016).

A major $\delta^{13} \mathrm{C}_{\text {org }}$ excursion $(-3.7 \% 0)$ is well marked at $53 \mathrm{~m}$ within a mature palaeosol and associated with a reverse magnetic polarity record, which is interpreted as the late C29r event known as the Dan-C2 event (Gilmour et al. 2014). It is followed by a long interval with no usable magnetic record. It is most likely that a part, or all, of chron C29n was truncated and not recorded as a result of fluvial erosion because it lies within conglomeratic and sandstone channel bodies. Significant hiatuses might therefore be present, which would result in the absence of lower C29n events.

The first negative excursion at $67 \mathrm{~m}$ corresponds to the base of chron C28r, representing the base of the rather long MLDME. This shows a positive trend followed by a negative peak similar to the defined MLDME of Zumaia, which lies between chrons C29n and C27r. The upper negative peak of the MLDME is prominent in the reference sections at Zumaia and Gubbio (Coccioni et al. 2012; Storme 2013) and in our dataset at c.120 m, for which a reverse polarity was measured and interpreted as chron C27r. In our dataset, the MLDME shows a long positive trend up to $c .108 \mathrm{~m}$ associated with records of magnetic reversal. The more positive values of the MLDME in the reference sections are within chron C28n, which can be placed on a thin interval at c. $108 \mathrm{~m}$ in the Lairière section, in which the base of chron C28n is marked by a conglomeratic body. The erosive nature of these sediments may explain a thin chron C28n.

\section{From the late Danian to Thanetian}

The most prominent excursion above the negative peak at $120 \mathrm{~m}$ is the sharp positive isotopic excursion at 168-171 m, the base of which is a major hiatus well expressed in the isotopic signal (by the horizontal gradient of the curve) and in the sedimentary record. It is related to a major extensive and erosive conglomerate fluvial body (L1) overlain by the main regional transgressive surface in the basin, laterally merging into one single transgressive erosional surface. The more positive values lie within rippled sandstones (L10, Table 1) directly overlying the transgressive surface.

Chron C27n, including the LDE (Arenillas et al.2008), can be partially recognized between the negative peak at $120 \mathrm{~m}$ and the sharp positive isotopic excursion at 168$171 \mathrm{~m}$. Chron C27n can be placed beneath the negative excursion at $152 \mathrm{~m}$ located at the 
top of a sandstone bed (L2), for which a reverse polarity was measured. Therefore the sandstone marks the boundary between chrons C27n and C26r.The LDE is often marked by a double-negative CIE in reference sections (Bornemann et al. 2009; Westerhold et al. 2011) and it is defined at Zumaia as the largest LDE starting at the beginning of chron C27n (Storme 2013). Only one peak could be attributed to this event in the Lairière section, but the sampling frequency is not as high resolution and we might have missed the full signal, or there may have been a hiatus. This event is considered to be a major hyperthermal event, with the temperature of the ocean increasing by $2^{\circ} \mathrm{C}$ (Westerhold et al. 2011) over 200 kyr (Bornemann et al. 2009).

The major hiatus observable by the sharp positive shift (>5\%) at $171.5 \mathrm{~m}$ encompasses the upper part of the DSTE. The base of the DSTE, which shows a well-marked negative trend followed by a positive trend at Zumaia, could correspond to a similar signal in the Lairière dataset from 152 to $171 \mathrm{~m}$, marking the end of Danian time. Therefore the Danian-Selandian boundary is interpreted at the base of the conglomerates (169 $\mathrm{m}$ ) lying directly beneath the transgression. The conglomerates represent condensed Early Selandian deposits related to the global sea-level lowstand. The hiatus under these conglomerates may also be early Selandian.

Two very negative CIEs at 175 and $185 \mathrm{~m}$ above the major unconformity (at $171.5 \mathrm{~m}$ ) could be correlated to the major part of the STTE event, which is also very negative in the $\delta^{13} \mathrm{C}_{\text {org }}$ of Zumaia (Storme 2013). At Lairière, a major negative CIE $(-3.7 \% 0)$ is followed by an abrupt positive shift between 187 and $196 \mathrm{~m}(+7.3 \%$ o). The base of the Thanetian is defined by the $\mathrm{C} 26 \mathrm{r}-\mathrm{C} 26 \mathrm{n}$ chron boundary and lies where ${ }^{13} \mathrm{C}_{\text {org }}$ shows a sharp shift from very negative to a recovery of more positive values in Zumaia. We therefore place this boundary at the Lairière section at $192 \mathrm{~m}$. Interestingly, the very negative CIE of the late Selandian seen in the $\delta{ }^{13} \mathrm{C}_{\text {org }}$ data at both Lairière and Zumaia is not observed in the $\delta^{13} \mathrm{C}_{\text {carb }}$ data from Gubbio (Coccioni et al. 2012) nor in the $\delta^{13} \mathrm{C}_{\mathrm{org}}$ of Sidi Nasseur (Tunisia; Storme 2013), where it shows a positive trend ending on a negative peak. This strongly negative CIE in the $\delta^{13} \mathrm{C}_{\text {org }}$ record might be a regional (Pyrenean) signal or a discrepancy between $\delta^{13} \mathrm{C}_{\text {org }}$ and $\delta^{13} \mathrm{C}_{\text {carb. }}$. It is not understood, but is beyond the scope of this study.

The marine sedimentary rocks above the main transgressive surface contain rare planktonic and benthonic forams, but these do not allow age determination. Dinocysts recovered from this interval are dominated by Glaphyrocysta ordinata and Glaphyrocysta 
pastielsii, which are common in European Selandian to early Ypresian successions, particularly in Selandian and Thanetian transgressive facies. Occurring with these taxa are the peridinioid dinocysts Apectodinium parvum and Apectodinium quinquelatum, species that do not occur in rocks older than the base of the Selandian (Williams et al.2015). The dinocyst assemblages recovered contrast with those recorded from the Danian of the Pyrenees (dinocyst zone D2 of Powell 1992) by GruasCavagnetto and Tambareau (1998), a shelf marine palynoflora including the Danian marker Alisocysta reticulata. An age no older than Selandian is supported by the absence of Normapolles species from the pollen and spore palynoflora. European Danian palynofloras are characterized by diverse and abundant Normapolles (e.g. Daly and Jolley 2015); this is not recorded in the studied section with the exception of Plicapollis pseudoexcelsus, which becomes extinct within the basal Ypresian. No Alveolina s.s. was found in the foram assemblage and therefore a Selandian age does not contradict the foram records. This first marine transgression within the Lairière succession was formerly attributed to the Early Thanetian (Tambareau et al. 1995), but is now believed to be uppermost Selandian in age based on the isotopic values and excursions and the palynology.

The recognition of a shallow marine Selandian interval in the terrestrial Pyrenean domain was unexpected because it is not recognized in the southern Pyrenean sections. Indeed, the Selandian in the Spanish shallow marine platform is interpreted as a major hiatus marked by a major karstification surface (Robador 2005). The distal part of the Pyrenean basin shows a major unconformity in the Paleocene platform in the Aquitaine foreland basin overlain by deeper facies, which is interpreted as a Selandian feature (Serrano 2001). To the west, the deeper Late Selandian facies at Zumaia exhibits a trangressive trends (Schmitz et al.2011) that is in concordance with Lairière sedimentary record.

\section{Mid- to Late Thanetian}

The overlying part of the succession at Lairière shows multiple excursions between the STTE and the sharp negative shift at $376 \mathrm{~m}$. The most obvious is the low-resolution trend above $200 \mathrm{~m}$. This $\delta{ }^{13} \mathrm{C}_{\text {org }}$ record shows a slight trend towards more positive values, with a maximum at $250 \mathrm{~m}$ followed by a slow trend towards more negative values. The swing of the $\delta^{13} \mathrm{C}_{\text {org }}$ trends is interpreted as the MTIM forming a small 
positive excursion, occurring at $250 \mathrm{~m}$ in the section at Lairière. It is well expressed at Gubbio and Zumaia and lies within the upper part of chron C25r (Fig. 2). A double negative peak is present at the end of the interpreted MTIM in Lairière and shows similarities with the peaks at Zumaia, the upper peak marking the limit between chrons C25r and C25n. The more negative excursion at the top of this low-resolution trend is very well marked in the three sections and we are confident in interpreting this excursion in the Lairière section as the C1 (known as the Lower C24r event) at $301 \mathrm{~m}$, despite no precise interpretable magnetic data to support this hypothesis.

The low resolution of the dataset above $301 \mathrm{~m}$ (Lower C24r), resulting from poor exposure and highly covered slopes, makes the interpretation less reliable. The upper part of the dataset shows some negative excursions (above $320 \mathrm{~m}$ ). The last robust stratigraphic anchor point is the thin marine bed at $375.5 \mathrm{~m}$, which is interpreted to be Thanetian by correlation with the Petites Pyrénées area (Tambareau et al. 1995).

\section{Identification of the Paleocene-Eocene boundary}

Recent studies in the Pyrenean domain have identified the PETM on $\delta_{13} \mathrm{C}_{\text {org }}$ data (Schmitz and Pujalte 2007; Domingo et al.2009; Manners et al. 2013; Minelli et al.2013; Storme 2013; Yans et al. 2014) as beneath the IMU (Fig. 3).The onset of the PETM is defined by a negative excursion and the most negative CIE with a relatively stable low value corresponds to the main body of the PETM event, with a plateau that may reflect a lag between the release and sequestration of carbon (Zachos 2005; Sluijs et al. 2007), followed by a recovery more positive than the beginning of the event. Both the upper Thanetian and PETM periods lie within chron C24r.

In the Late part of the study section, between 376 and $425 \mathrm{~m}$, the values of $\delta{ }^{13} \mathrm{C}_{\text {org }}$ decrease with a maximum range of $-3.7 \%$. This interval shows a sharp shift at $376 \mathrm{~m}$ corresponding to a small negative excursion followed by a larger negative peak (maximum negative value at $410 \mathrm{~m}$ ). The first small peak could be interpreted as the initiation of the PETM, but the major negative CIE is well defined between 385 and 425 $\mathrm{m}$, the base of which is within the thick interval with no data. It is interpreted as the main body of the PETM event (Figs 2 and 3). The overlying interval, starting at $425 \mathrm{~m}$, may also contain a part of the PETM event representing the recovery phase, lasting up to 438 or $467 \mathrm{~m}$. 
Yans et al. (2014) identified two intervals in the nearest section (i.e. the Albas section) that could be interpreted as the PETM event (Fig. 3): option 1 is $30 \mathrm{~m}$ thick and $60 \mathrm{~m}$ below the base of the IMU and option 2 is $20 \mathrm{~m}$ thick and $10 \mathrm{~m}$ below the IMU. In the Lairière section, the CIE onset of the PETM is $c .60 \mathrm{~m}$ below the base of the IMU and spreads over an interval $30 \mathrm{~m}$ (for the body) thick (Fig. 3). Thus option 2 (from Yans et al. 2014) fits the Lairière dataset better for both TOC content and $\delta^{13} \mathrm{C}_{\mathrm{org}}$ (Figs 2 and 3). Option 1 of Yans et al. (2014) could be interpreted as an earlier CIE, potentially the C1 event (Fig. 3).

The PETM interval in the Spanish Pyrenees is identified at Claret and Tendruy in the Tremp basin (Domingo et al. 2009) and in the Ager basin (Minelli et al. 2013; Fig. 3), displaying a thickness of $60 \mathrm{~m}$ and a $\delta^{13} \mathrm{C}_{\text {org }}$ pattern with a negative trend of $-3 \%$, with a recovery overlying phase with more positive values. This is consistent with our interpretation (Fig. 3). At Zumaia, a very negative CIE $(-4 \% 0)$ in the $\delta_{13} C_{\text {org }}$ dataset represents the PETM event (Storme et al. 2012) over a $5 \mathrm{~m}$ interval. The PETM interval is a key stratigraphic interval marked by a CIE magnitude and shape that enables us to place the P-E boundary in the Pyrenean continental deposits.

\section{Variability of the $\delta^{13} C_{o r g}$ signal}

Because the Lairière section was formed in different sedimentary environments, the type of organic matter may be variable throughout the Paleocene succession and may trigger a bias in the $\delta^{13} \mathrm{C}_{\text {org }}$ signal. The preserved organic matter in the floodplain and channel deposits is most likely to be pollen and spores from the catchment area and the in situ floodplain, eventually forming coal fragments. The floodplains were highly vegetated under the warm conditions of the subtropical to tropical climate (Plaziat 1984). The organic matter in the lacustrine deposits probably also contains some algal materials, whereas the organic matter in the shallow marine deposits is probably a mixture of terrestrial material, planktonic and algal marine organic components; coal debris is abundant in some beds. Therefore care has to be taken when interpreting the $\delta{ }^{13} \mathrm{C}_{\text {org }} \mathrm{CIE}$ as the variations might be due to a change in organic matter that has an intrinsically different $\delta{ }^{13} \mathrm{C}_{\text {org }}$ value due to initial fractionation rather than to global changes (Dunkley Jones et al. 2018). For example, algae preferentially integrate ${ }^{13} \mathrm{C}$ into

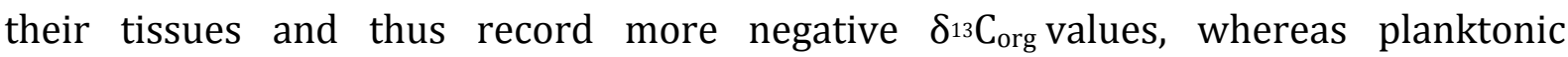
organisms show more positive values (Heimhofer 2004; Zhu et al. 2011). The samples in 
this dataset come from floodplain and channel deposits (70\%), for which similar types of organic matter can be assumed, although we could argue that the organic matter transported by channel rivers might be reworked from older catchment rocks and therefore modify the measured signal. Twelve (10\%) samples came from marine sediments, 24 (20\%) from continental carbonate sediments and only four $(<1 \%)$ from detrital lacustrine delta front sediments.
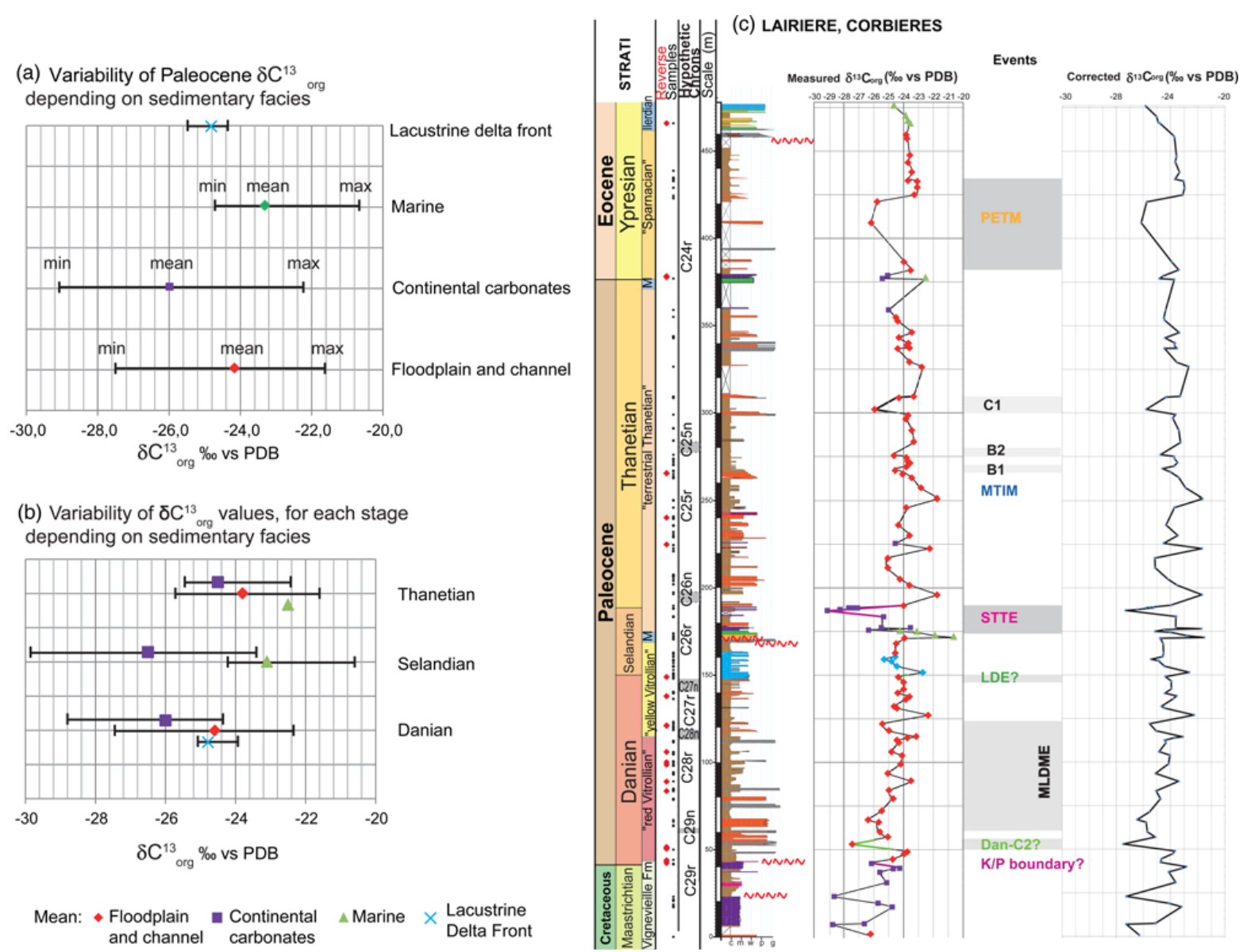

Figure 4. (a) Dependence of the variability of Paleocene $\delta^{13} \mathrm{C}_{\mathrm{org}}$ values throughout the section on sedimentary facies. (b) Variability of $\delta{ }^{13} \mathrm{C}_{\text {org }}$ values for each stage depending on the sedimentary facies. (c) Lairière section showing the measured $\delta^{13} C_{\text {org }}$ and interpreted global events in Figure 2 and a corrected $\delta{ }^{13} \mathrm{C}_{\text {org }}$ record throughout the section recalculated using the mean values of the fluvial and floodplain facies to test whether the interpreted global events were still observable when attempting to avoid a potential change in organic matter linked with the depositional environment. PETM, Palaeocene Eocene Thermel Maximum; MTIM, Mid-Thanetian Isotope Maximum; LLDE, Large Latest Danian Event; DSTE, Danian-Selandien Transition Event; STTE, Selandien Thanetian Transition Event; CIE, Carbon isotope excursion.

Although the average value in this dataset is $-24.5 \%$, the most negative values are recorded in continental carbonates at 7 and $23 \mathrm{~m}(-28.8 \%)$ at $186 \mathrm{~m}$ (-29.1\%o; Fig. $4 a, b)$ and, less dramatically, at 176 and 377 m ( -26.3 and $-25.5 \%$, respectively). These 
continental carbonates also show positive peaks in other intervals (e.g. $-24.7 \%$ at 17 m). Interestingly, the rippled sandstone lithofacies L10, which contains abundant coal fragments, does not appear to bear as negative a signal ( -27.5 to $-21.6 \%)$ as expected from the coal debris, which should bear very negative $\delta^{13} \mathrm{C}_{\text {org }}(-28.5$ to -23.9\%o; Warwick and Ruppert 2016). In the light of these discrepancies, we attempted to calculate the mean signal for the geochemical data based on the sedimentary facies and therefore on the depositional environment, which may reflect a variability in the organic matter. Calculations were made for the entire Paleocene (Fig. 4a) and for the different stages defined in our stratigraphic scheme (Fig. 4b). The most negative values (minimum and mean) were measured in continental carbonates, whereas the most positive values (mean and maximum) were measured in shallow marine sediments. However, parts of the continental carbonates were within the range of marine values. The variations in the floodplain and channel facies values were wide and within the range of continental carbonates and marine values. Despite the small number of samples in lacustrine delta front settings, we could not ignore the fact that the range values were between the floodplain and channel mean and the lacustrine carbonate mean (Fig. 4a). Figure $4 \mathrm{~b}$ shows the mean $\delta^{13} \mathrm{C}_{\text {org }}$ values for each stage depending on the sedimentary facies. For each depositional environment the mean values show a shift to more positive values from the Danian-Selandian to Thanetian, potentially indicating an atmospheric change in the Thanetian world, although our datasets for continental carbonates and marine values are not well expanded. As a result of the rarity (in only one Danian interval) and low numbers of lacustrine delta front samples, this dataset cannot show the evolution through time, but its variability around the floodplain and channel mean value show that these deposits bear a signal equivalent to the floodplain and channel samples. They do not show the more negative signal expected if lacustrine algae are mixed in the sediments. These samples are therefore treated as floodplain and channel samples in the following discussion.

A peculiar negative mean value for continental carbonates in the Selandian might not only be a result of environmental bias. These values are within the STTE, for which the Pyrenean realm shows a very prominent negative excursion. To test the robustness of the CIE defined as globally correlatable, we corrected the dataset to guess how it would appear if the samples were only from floodplain or channel deposits. To do so, we applied a new value to every marine and continental carbonate sample by calculating 
the difference between the measured values and the variations between the mean value of the marine or continental carbonates samples and the mean value of the floodplain/channel samples. For each continental carbonate sample, we therefore added $+1.5 \%$ o for the Danian, $1.8 \%$ for the Selandian and $0.6 \%$ or the Thanetian, whereas for each marine sample we removed $-0.9 \%$ for the Selandian and Thanetian to obtain a Paleocene signal corrected for facies and potential environmental variations (Fig. 4c). The excursions were of a lower amplitude, but, despite the correction, the clear CIEs can still be recognized, so we believe that they can be interpreted as a global change and not only to major changes in the type of organic matter within samples. However, it seems evident that a more systematic and detailed analysis should be carried out to understand the variations in ${ }^{13} \mathrm{C}_{\mathrm{org}}$. Their use as correlation scheme could be improved, but the size of the organic matter particles does not allow us to pursue this analysis.

\section{Conclusions}

This study provides a new, large $\delta{ }^{13} \mathrm{C}_{\text {org }}$ dataset along a thick, dominantly terrestrial, succession from the latest Maastrichtian to earliest Eocene, together magnetostratigraphic data to double-calibrate the section. Our aim is to bring temporal constraints to continental successions. Eleven geochemical global events from the Paleocene to early Eocene were identified along the succession (namely the K-P, DanC2, MLDME, LDE, DSTE, STTE, MTIM, B1, B2, C1 and PETM events) as a result of highresolution correlations established with calibrated sections in the Pyrenees (Zumaia, Spain) and the Alpine system (Gubbio, Italy). We successfully constrained the chronostratigraphy by refining the location of the K-Pg boundary, suggesting a major hiatus in chron C29n and proving a major hiatus within the Early Selandian, demonstrating the occurrence of late Selandian deposits, placing the SelandianThanetian boundary in this area for the first time, and providing evidence for the P-E boundary with the well-marked PETM CIE.

We suggest that using carbon isotopes on organic matter $\left(\delta^{13} \mathrm{C}_{\mathrm{org}}\right)$ is a good way to refine the stratigraphy in continental deposits, but particular caution must be taken in the interpretation of the signals due to the existence of sedimentary hiatuses and the potential variation in the type of organic matter type. Changes in the type of organic matter could induce shifts in the $\delta^{13} \mathrm{C}_{\text {org }}$ signal that are not related to atmospheric global changes and therefore cannot be used as a correlation tool. We propose an original 
analysis for our dataset that looked at the signal in terms of the depositional environment and the potential changes in organic matter. After calculating a corrected $\delta^{13} \mathrm{C}_{\text {org }}$ (based on the mean floodplain and channel values), we compared the primary measured and corrected excursions and determined that all the major CIEs were still present. We believe that this correction is a first approach to reduce signal bias and that $\delta^{13} \mathrm{C}_{\mathrm{org}}$ can be used, with caution, as a global correlation tool.

From a regional point of view, the recognition of a major lower Selandian hiatus related to both conglomerates and a transgressive erosional surface and associated with a major CIE is unique. These data, together with the occurrence of transgressive facies associated with the most negative isotopic CIE, is the strongest argument for interpreting the presence of an uppermost Selandian unit in this easternmost Pyrenean domain as a result of the similarities with both the sedimentary trends and the $\delta{ }^{13} \mathrm{C}_{\text {org }}$ CIE of Zumaia (the STTE event, Storme 2013). Palynological analysis confirmed a potential Selandian age. Those newly interpreted Selandian units of the Corbières contrast sharply with the palaeogeographical reconstructions of some other researchers that indicate a deep marine connection between the Bay of Biscay and SE France through the Languedoc area (e.g. Peybernes et al. 2001), but is in agreement with other palaeogeographical reconstructions of punctuated shallow marine gulfs within the Pyrenean continental realm throughout the Paleocene (Plaziat 1981; Tambareau et al. 1995; Husson 2013). Nevertheless, it also contrasts with the southern Pyrenean basin where the Selandian is entirely missing (e.g. Pujalte et al.2014). The P-E boundary and PETM CIE recognized elsewhere in the Pyrenees is also present in this Lairière section and lies within continental sediments beneath the Ilerdian marine deposits. Interestingly, despite the conglomerates punctuating the Paleocene succession at Lairière, no conglomeratic bed coincides with the onset of the PETM as seen with the Claret Conglomerate in Spain (e.g. Domingo et al. 2009). The Claret Conglomerate has been interpreted as a climatically driven deposit due to the intense rainfall associated with the PETM (Pujalte et al. 2014; Chen et al. 2018), but the Lairière dataset does not support this hypothesis, showing the complexity of sedimentary record relative to external controls.

\section{Acknowledgements}


This paper has greatly benefited from thorough reviews by R. Duller and S.J. Jones. We are grateful to Christine Fléhoc and Michaela Blessing for their help in the geochemistry laboratory of the BRGM in Orléans with the total organic carbon and $\delta{ }^{13} \mathrm{C}_{\text {org }}$ measurements, and to Florence Quesnel (BRGM) for her advice on the isotopic methodology and discussions about the Paleocene, Cretaceous-Paleogene and Paleocene-Eocene boundaries. We are grateful to Alina I. Iakovleva (Geological Institute, Russian Academy of Sciences, Moscow) for help with the dinoflagellate cysts and Delphine Desmares (Sorbonne University, Paris). Additional palynology samples were prepared by Dave Bodman (MB Stratigraphy, Sheffield, UK). Thanks are given to Thierry Baudin, Philippe Razin, Pierre Nehlig, Isabelle Thinon and Caroline Ricordel-Prognon for their support and discussions regarding the geology of the Pyrenees.

\section{Funding}

This study is part of a PhD project funded by the French government. The analyses were funded thanks to the BRGM/RGF grants. Constance Vinciguerra thanks the OROGEN project (Total/BRGM/CNRS) for her PhD funding.

\section{References}

Allen, J.R.L. 1985. Principles of Physical Sedimentology. Springer Netherlands, Dordrecht . https://doi.org/10.1007/978-94-010-9683-6

Alvarez, L.W., Alvarez, W., Asaro, F. and Michel, H.V. 1980. Extraterrestrial cause for the Cretaceous-Tertiary extinction. Science , 208, 1095-1108, https://doi.org/10.1126/science.208.4448.1095

Arenillas, I., Molina, E., Ortiz, S. and Schmitz, B. 2008. Foraminiferal and $\Delta 13 \mathrm{C}$ isotopic event-stratigraphy across the Danian-Selandian transition at Zumaya (northern Spain): chronostratigraphic implications. Terra Nova , 20, 38-44, https://doi.org/10.1111/j.1365-3121.2007.00784.x

Arens, N.C. and Jahren, A.H. 2000. Carbon isotope excursion in atmospheric CO2 at the Cretaceous-Tertiary boundary: evidence from terrestrial sediments. Palaios , 15, 314-322, https://doi.org/10.1669/0883-1351(2000)015<0314:CIEIAC>2.0.CO;2

Aubry, M.P., Ouda, K. et al 2007. The global standard stratotype-section and point (GSSP) for the base of the Eocene series in the Dababiya section (Egypt). Episodes , 30, 271-286, https://doi.org/10.18814/epiiugs/2007/v30i4/003

Baceta, J.I., Pujalte, V. and Bernaola, G. 2005. Paleocene coralgal reefs of the western Pyrenean Basin, northern Spain: new evidence supporting an earliest Paleogene recovery of reefal ecosystems. Palaeogeography, Palaeoclimatology, Palaeoecology , 224, 117-143, https://doi.org/10.1016/j.palaeo.2005.03.033

Bachman, G.O. and Machette, M.N. 1977. Calcic Soils and Calcretes in the Southwestern United States . US Geological Survey Open-File Report 77-794, https://doi.org/10.3133/ofr7779

Bergerg, M., Bessiere, G., Bilotte, M. and Viallard, P. 1997. Carte géol. France (1/50 000), feuille Tuchan (1078). Orléans: BRGM. Notice explicative par Berger, G.M., Alabouvette, B., Bessière, G., Bilotte, M., Crochet, B., Dubar, M., Marchai, J.P., Tambareau, Y., Villaîte, J., Viallard, P. 113.

Bernaola, G., Baceta, J.I., Orue-Etxebarria, X., Alegret, L., Martin-Rubio, M., Arostegui, J. and Dinares-Turell, J. 2007. Evidence of an abrupt environmental disruption during the mid-Paleocene biotic event (Zumaia Section, western Pyrenees). 
Geological Society of America Bulletin , 119, 785-795, https://doi.org/10.1130/B26132.1

Bilotte, M. and Canerot, J. 2006. Rôles respectifs des tectoniques fini-Crétacée et Éocène dans la partie orientale de la chaîne des Pyrénées. Le «Garumnien» de Cucugnan et ses relations avec le chevauchement frontal Nord-Pyrénéen (Corbières Méridionales, France). Eclogae Geologicae Helvetiae , 99, 17-27, https://doi.org/10.1007/s00015-006-1179-8

Bluck, B.J. 1979. Structure of coarse grained braided stream alluvium. Earth and Environmental Science. Transactions of The Royal Society of Edinburgh , 70, 181221. https://doi.org/10.1017/S0080456800012795

Bonté, P., Delacotte, O., Renard, M., Laj, C., Boclet, D., Jehanno, C. and Rocchia, R. 1984. An iridium rich layer at the Cretaceous/Tertiary boundary in the Bidart section (southern France). Geophysical Research Letters , 11, 473-476, https://doi.org/10.1029/GL011i005p00473

Bornemann, A., Schulte, P., Sprong, J., Steurbaut, E., Youssef, M. and Speijer, R.P. 2009. Latest Danian carbon isotope anomaly and associated environmental change in the southern Tethys (Nile Basin, Egypt). Journal of the Geological Society, London , 166, 1135-1142, https://doi.org/10.1144/0016-76492008-104

Bowen, G.J., Koch, P.L., Gingerich, P.D., Norris, R.D., Bains, S. and Corfield, R.M. 2001. Refined isotope stratigraphy across the continental Paleocene-Eocene boundary on Polecat Bench in the northern Bighorn Basin. University of Michigan, Museum of Paleontology, Papers on Paleontology, 33, 73-88.

Bridge, J.S. 2007. Rivers and Floodplains: Forms, Processes, and Sedimentary Record . Blackwell, Malden, MA.

Canérot, J. and Rey, J. 2008. Les Pyrénées: histoire géologique et itinéraires de découverte . Biarritz Atlantica [Orléans] BRGM éd. impr. 2008.

Cerling, T.E. and Quade, J. 1993. Stable carbon and oxygen isotopes in soil carbonates. American Geophysical Union, Geophysical Monograph Series , 78, 217-231, https://doi.org/10.1029/GM078p0217

Chantraine, J., Autran, A. et al 1996. Carte Géologique de la France au 1/1000000: France, Bureau de Recherche et de Géologique Minière.

Chen, C., Guerit, L. et al 2018. Estimating regional flood discharge during PalaeoceneEocene global warming. Scientific Reports , 8, 13391, https://doi.org/10.1038/s41598-018-31076-3

Christophoul, F., Soula, J.C., Brusset, S., Elibana, B., Roddaz, M., Bessiere, G. and Deramond, J. 2003. Time, place and mode of propagation of foreland basin systems as recorded by the sedimentary fill: examples of the Late Cretaceous and Eocene retro-foreland basins of the north-eastern Pyrenees. Geological Society, London, Special Publications , 208, 229-252, https://doi.org/10.1144/GSL.SP.2003.208.01.11

Coccioni, R., Bancalà, G. et al 2012. An integrated stratigraphic record of the PalaeoceneLower Eocene at Gubbio (Italy): new insights into the Early Palaeogene hyperthermals and carbon isotope excursions. Terra Nova , 24, 380-386, https://doi.org/10.1111/j.1365-3121.2012.01076.x

Cohen, K.M., Finney, S.C., Gibbard, P.L. and Fan, J.-X. 2013. The ICS International Chronostratigraphic Chart. Episodes , 36, 199-204, https://doi.org/10.18814/epiiugs/2013/v36i3/002 
Cojan, I. 2000. Stable carbon isotope stratigraphy of the Paleogene pedogenic series of southern France as a basis for continental-marine correlation. Geology , 28, 259262, https://doi.org/10.1130/0091-7613(2000)28<259:SCISOT >2.0.CO;2

Cojan, I., Renard, M. and Emmanuel, L. 2003. Palaeoenvironmental reconstruction of dinosaur nesting sites based on a geochemical approach to eggshells and associated palaeosols (Maastrichtian, Provence Basin, France). Palaeogeography, Palaeoclimatology, Palaeoecology , 191, 111-138, https://doi.org/10.1016/S00310182(02)00655-7

Daly, R.J. and Jolley, D.W. 2015. What was the nature and role of Normapolles angiosperms? A case study from the earliest Cenozoic of Eastern Europe. Palaeogeography, Palaeoclimatology, Palaeoecology , 418, 141-149, https://doi.org/10.1016/j.palaeo.2014.10.014

Díaz-Molina, M. 1993. Geometry and Lateral Accretion Patterns in Meander Loops: Examples from the Upper Oligocene-Lower Miocene, Loranca Basin, Spain. In: Marzo, M. and Puigdefbregas, C. (eds) Alluvial Sedimentation . Blackwell Publishing Ltd., Oxford, UK, 115-131. https://doi.org/10.1002/9781444303995.ch10

Dickens, G.R., O'Neil, J.R., Rea, D.K. and Owen, R.M. 1995. Dissociation of oceanic methane hydrate as a cause of the carbon isotope excursion at the end of the Paleocene. Paleoceanography , 10, 965-971, https://doi.org/10.1029/95PA02087

Dinarès-Turell, J., Baceta, J.I., Bernaola, G., Orue-Etxebarria, X. and Pujalte, V. 2007. Closing the Mid-Palaeocene gap: toward a complete astronomically tuned Palaeocene Epoch and Selandian and Thanetian GSSPs at Zumaia (Basque Basin, W Pyrenees). Earth and Planetary Science Letters , 262, 450-467, https://doi.org/10.1016/j.epsl.2007.08.008

Domingo, L., López-Martínez, N., Leng, M.J. and Grimes, S.T. 2009. The Paleocene-Eocene thermal maximum record in the organic matter of the Claret and Tendruy continental sections (south-central Pyrenees, Lleida, Spain). Earth and Planetary Science Letters , 281, 226-237, https://doi.org/10.1016/j.epsl.2009.02.025

Driscoll, N.W. and Karner, G.D. 1999. Three-dimensional quantitative modeling of clinoform development. Marine Geology , 154, 383-398, https://doi.org/10.1016/S0025-3227(98)00125-X

Dunkley Jones, T., Manners, H.R. et al 2018. Dynamics of sediment flux to a bathyal continental margin section through the Paleocene-Eocene thermal maximum. Climate of the Past , 14, 1035-1049, https://doi.org/10.5194/cp-14-1035-2018

Dupuis, C., Steurbaut, E. et al 2001. The Cretaceous-Palaeogene (K/P) boundary in the Aïn Settara section (Kalaat Senan, Central Tunisia): lithological, micropalaeontological and geochemical evidence. Bulletin de l'Institut Royal des Sciences Naturelles de Belgique, Sciences de la Terre .

Filleaudeau, P.-Y., Mouthereau, F. and Pik, R. 2012. Thermo-tectonic evolution of the south-central Pyrenees from rifting to orogeny: insights from detrital zircon $\mathrm{U} / \mathrm{Pb}$ and (U-Th)/He thermochronometry. Basin Research , 24, 401-417, https://doi.org/10.1111/j.1365-2117.2011.00535.x

Flügel, E. 2010. Microfacies of Carbonate Rocks . Springer, Berlin.

Fondevilla, V., Dinarès-Turell, J., Vila, B., Le Loeuff, J., Estrada, R., Oms, O. and Galobart, A. 2016. Magnetostratigraphy of the Maastrichtian continental record in the upper Aude valley (northern Pyrenees, France): placing age constraints on the succession of dinosaur-bearing sites. Cretaceous Research , 57, 457-472, https://doi.org/10.1016/j.cretres.2015.08.009 
Ford, M., Hemmer, H., Vacherat, A., Gallagher, K. and Christophoul, F. 2016. Retro-wedge foreland basin evolution along the ECORS line, eastern Pyrenees, France. Journal of the Geological Society, London , 173, 419-437, https://doi.org/10.1144/jgs2015129

Freytet, P. 1970. Les dépôts continentaux et marins du Crétacé supérieur et des couches de passage à l'Eocène en Languedoc . PhD thesis, Université Paris-Sud Orsay.

Freytet, P. and Plaziat, J.-C. 1982. Continental Carbonate Sedimentation and Pedogenesis - Late Cretaceous and Early Tertiary of Southern France. Contributions to Sedimentology, 12. Schweizerbart, Stuttgart.

Freytet, P. and Verrecchia, E.P. 2002. Lacustrine and palustrine carbonate petrography: an overview. Journal of Paleolimnology , 27, 221-237, https://doi.org/10.1023/A:1014263722766

Gély, J.P. and Sztràkos, K. 2000. L'évolution paléogéographique et géodynamique du Bassin aquitain au Paléogène: enregistrement et datation de la tectonique pyrénéenne. Géologie de la France , 31-57.

Gibling, M.R. 2006. Width and thickness of fluvial channel bodies and valley fills in the geological record: a literature compilation and classification. Journal of Sedimentary Research , 76, 731-770, https://doi.org/10.2110/jsr.2006.060

Gilmour, L., Jolley, D., Kemp, D., Kelley, S., Gilmour, M., Daly, R. and Widdowson, M. 2014. The early Danian hyperthermal event at Boltysh (Ukraine): relation to CretaceousPaleogene boundary events. Geological Society of America, Special Papers, 505, 133-146.

Gruas-Cavagnetto, C. and Tambareau, Y. 1998. Palynologie du Selandian d'Oraas (Pyrenees-Atlantiques, France): comparison avec le microplancton du DanienSelandien connu dans le monde. Geodiversitas , 20, 239-261.

Gruas-Cavagnetto, C., Tambareau, Y. and Villatte, J. 1992. Découverte de pollens, dinoflagellés et forminifères dans le Danien des petites pyrénées: implications sur la position de la limite Crétacé/Tertiaire. Geobios , 25, 19-28, https://doi.org/10.1016/S0016-6995(06)80310-4

Hampson, G.J. 2010. Sediment dispersal and quantitative stratigraphic architecture across an ancient shelf. Sedimentology , 57, 96-141, https://doi.org/10.1111/j.1365-3091.2009.01093.x

Heimhofer, U. 2004. Response of terrestrial paleoenvironments to past changes in climate and carbon-cycling: insights from palynology and stable isotope geohemistry . PhD thesis, University of Zurich.

Husson, E. 2013. Interaction géodynamique/karstification et modélisation géologique 3D des massifs carbonatés: Implication sur la distribution prévisionnelle de la karstification. Exemple des paléokarts crétacés à néogènes du Languedoc montpelliérain. PhD Thesis, Université Montpellier II - Sciences et Techniques du Languedoc.

Jacobs, B.F., Kingston, J.D. and Jacobs, L. 1999. The origin of grass-dominated ecosystems. Annals of the Missouri Botanical Garden , 86, 590, https://doi.org/10.2307/2666186

Jolley, D., Gilmour, L., Gurov, E., Kelley, S. and Watson, J. 2010. Two large meteorite impacts at the Cretaceous-Paleogene boundary. Geology , 38, 835-838, https://doi.org/10.1130/G31034.1

Keller, G. and Lindinger, M. 1989. Stable isotope, TOC and CaCO3 record across the Cretaceous/Tertiary boundary at El Kef, Tunisia. Palaeogeography, 
Palaeoclimatology, Palaeoecology , 73, 243-265, https://doi.org/10.1016/00310182(89)90007-2

Kelley, S. and Gurov, E. 2002. Boltysh, another end-Cretaceous impact. Meteoritics \& Planetary Science , 37, 1031-1043, https://doi.org/10.1111/j.19455100.2002.tb00875.x

Knox, R.W.O'B. and Morton, A.C. 1988. The record of Early Tertiary N Atlantic volcanism in sediments of the North Sea Basin. Geological Society, London, Special Publications , 39, 407-419, https://doi.org/10.1144/GSL.SP.1988.039.01.36

Koch, P.L. 1998. Isotopic reconstruction of past continental environments. Annual Review of Earth and Planetary Sciences , 26, 573-613, https://doi.org/10.1146/annurev.earth.26.1.573

Koch, P.L., Clyde, W.C., Hepple, R.P., Fogel, M.L., Wing, S.L. and Zachos, J.C. 2003. Carbon and oxygen isotope records from paleosols spanning the Paleocene-Eocene boundary, Bighorn Basin, Wyoming. Geological Society of America, Special Papers, 369, 49-64.

Koch, P.L., Zachos, J.C. and Gingerich, P.D. 1992. Correlation between isotope records in marine and continental carbon reservoirs near the Paleocene/Eocene boundary. Nature , 358, 319-322, https://doi.org/10.1038/358319a0

Lepicard, B., Bilotte, M., Massieux, M., Tambareau, Y. and Villatte, J. 1985. Faunes et flores au passage Crétacé-Tertiaireen faciès continental dans les Petites Pyrénées (Zone sous-pyrénéenne). Geobios , 18, 787-805, https://doi.org/10.1016/S00166995(85)80035-8

Lopez, S. and Cojan, I. 2000. Chemostratigraphy of the Lower Miocene Beynes Châteauredon series (Alpes-de-Hautes-Provence). Comptes Rendus de la Académie des Sciences - Series IIA - Earth and Planetary Science , 330, https://doi.org/10.1016/S1251-8050(00)00224-X.

Magioncalda, R., Dupuis, C., Smith, T., Steurbaut, E. and Gingerich, P. 2004. PaleoceneEocene carbon isotope excursion in organic carbon and pedogenic carbonate: direct comparison in a continental stratigraphic section. Geology , 32, 553., https://doi.org/10.1130/G20476.1

Manners, H.R., Grimes, S.T. et al 2013. Magnitude and profile of organic carbon isotope records from the Paleocene-Eocene thermal maximum: evidence from northern Spain. Earth and Planetary Science Letters , 376, 220-230, https://doi.org/10.1016/j.epsl.2013.06.016

Martinius, A.W. 2000. Labyrinthine Facies Architecture of the Tortola Fluvial System and Controls on Deposition (Late Oligocene-Early Miocene, Loranca Basin, Spain). Journal of Sedimentary Research , 70, 850-867, https://doi.org/10.1306/2DC4093D-0E47-11D7-8643000102C1865D

Marty, D. and Meyer, C. 2006. Depositional conditions of carbonate-dominated palustrine sedimentation around the K-T boundary (Faciès Rognacien, northeastern Pyrenean foreland, southwestern France). Geological Society of America, Special Papers, 416, 169-187. https://doi.org/10.1130/2006.2416(11)

McConnaughey, T.A. and Whelan, J.F. 1997. Calcification generates protons for nutrient and bicarbonate uptake. Earth Science Reviews , 42, 95-117, https://doi.org/10.1016/S0012-8252(96)00036-0

McInerney, F.A. and Wing, S.L. 2011. The Paleocene-Eocene Thermal Maximum: A Perturbation of Carbon Cycle, Climate, and Biosphere with Implications for the Future. Annual Review of Earth and Planetary Sciences , 39, 489-516. https://doi.org/10.1146/annurev-earth-040610-133431 
Miall, A.D. 2006. The Geology of Fluvial Deposits . Springer, Berlin, https://doi.org/10.1007/978-3-662-03237-4.

Minelli, N., Manzi, V. and Roveri, M. 2013. The record of the Paleocene-Eocene thermal maximum in the Ager Basin (Central Pyrenees, Spain). Geologica Acta , 11, 421441, https://doi.org/10.1344/105.000002061.

Minoletti, F., de Rafelis, M., Renard, M. and Gardin, S. 2004. Remaniement des nannofossiles calcaires maastrichtiens dans les sédiments du Danien basal de Bidart (France): arguments isotopiques (carbone et oxygène). Revue de Micropaléontologie , 47, 145-152, https://doi.org/10.1016/j.revmic.2004.07.001

Molina, E., Alegret, L. et al 2006. The global boundary stratotype section and point for the base of the Danian stage (Paleocene, Paleogene, "Tertiary", Cenozoic) at El Kef, Tunisia - original definition and revision. Episodes , 29, 263, https://doi.org/10.18814/epiiugs/2006/v29i4/004

Nadon, G.C. 1994. The Genesis and Recognition of Anastomosed Fluvial Deposits: Data from the St. Mary River Formation, Southwestern Alberta, Canada. Journal of Sedimentary Research 64, 451-463, https://doi.org/10.1306/D4267FE1-2B2611D7-8648000102C1865D

Nanson, G.C. and Croke, J.C. 1992. A genetic classification of floodplains. Geomorphology , 4, 459-486. https://doi.org/10.1016/0169-555X(92)90039-Q

Olivet, J.L. 1996. La cinématique de la plaque ibérique. Bulletin des Centres de Recherche, 323 d'Exploration et de Production d'Elf-Aquitaine , 21, 131-195.

Petrizzo, M.R. 2005. An early late Paleocene event on Shatsky Rise, northwest Pacific Ocean (ODP Leg 198): evidence from planktonic foraminiferal assemblage. Proceedings of the ODP, Scientific Results, 1-29, https://doi.org/10.2973/odp.proc.sr.198.102.2005.

Peybernès, B., Fondecave-Wallez, M.-J., Combes, P.-J. and Eichène, P. 2001. Mise en évidence d'un sillon marin à brèches paléocènes dans les Pyrénées centrales (Zone interne métamorphique et Zone nord-pyrénéenne). Comptes Rendus de l'Académie des Sciences - Series IIA - Earth and Planetary Science , 332, 379-386. https://doi.org/10.1016/S1251-8050(01)01545-2

Plaziat, J.-C. 1966. Contribution à l'étude paléontologique et sédimentologique du Sparnacien des Corbières Septentrionales (Aude) . PhD thesis, Université Paris-Sud (Orsay).

Plaziat, J.-C. 1975. L'Ilerdien a l'interieur du Paleogene Languedocien; ses relations avec le Sparnacien, l'Ilerdien sud-Pyreneen, l'Ypresien et le Paleocene. Bulletin de la Société géologique de France , S7-XVII, 168-182, https://doi.org/10.2113/gssgfbull.S7-XVII.2.168

Plaziat, J.-C. 1981. Late Cretaceous to Late Eocene palaeogeographic evolution of southwest Europe. Palaeogeography, Palaeoclimatology, Palaeoecology , 36, 263320, https://doi.org/10.1016/0031-0182(81)90110-3

Plaziat, J.-C. 1984. Stratigraphie et évolution paléogéographique du domaine pyrénéen de la fin du crétacé (phase Maastrichtienne) à la fin de l'éocène (phase pyrénéenne) . PhD thesis, Université Paris-Sud (Orsay).

Pollard, J.E., Steel, R.J. and Undersrud, E. 1982. Facies sequences and trace fossils in lacustrine/ an delta deposits, Hornelen Basin (M. Devonian), western Norway. Sedimentary Geology , 32, 63-87, https://doi.org/10.1016/0037-0738(82)900148

Pomar, L. 2001. Types of carbonate platforms: a genetic approach. Basin Research , 13, 313-334, https://doi.org/10.1046/j.0950-091x.2001.00152.x 
Powell, A.J. 1992. A Stratigraphic Index of Dinoflagellate Cysts . Chapman \& Hall, London. Pujalte, V. 2009. Redefinition of the Ilerdian Stage (Early Eocene). Geologica Acta , 7, https://doi.org/10.1344/105.000000268

Pujalte, V., Baceta, J.I. and Schmitz, B. 2015. A massive input of coarse-grained siliciclastics in the Pyrenean Basin during the PETM: the missing ingredient in a coeval abrupt change in hydrological regime. Climate of the Past , 11, 1653-1672, https://doi.org/10.5194/cp-11-1653-2015

Pujalte, V., Schmitz, B. and Baceta, J.I. 2014. Sea-level changes across the PaleoceneEocene interval in the Spanish Pyrenees, and their possible relationship with North Atlantic magmatism. Palaeogeography, Palaeoclimatology, Palaeoecology , 393, 45-60, https://doi.org/10.1016/j.palaeo.2013.10.016

Renne, P.R., Deino, A.L. et al 2013. Time scales of critical events around the CretaceousPaleogene boundary. Science 339, 684-687, https://doi.org/10.1126/science.1230492

Renne, P.R., Sprain, C.J., Richards, M.A., Self, S., Vanderkluysen, L. and Pande, K. 2015. State shift in Deccan volcanism at the Cretaceous-Paleogene boundary, possibly induced by impact. Science , 350, 76-78, https://doi.org/10.1126/science.aac7549

Rich, J.L. 1951. Three critical environments of deposition, and criteria for recognition of rocks deposited in each of them. Bulletin of the Geological Society of America , 62, 1-20, https://doi.org/10.1130/0016-7606(1951)62[1:TCEODA]2.0.C0;2

Robador, A. 2005. El paleoceno e ilerdiense inferior del pirineo occidental: estratigrafía y sedimentología, PhD thesis, Universidad del País Vasco Euskal Herriko Unibertsitatea.

Röhl, U., Westerhold, T., Bralower, T. and Zachos, J.C. 2007. On the duration of the Paleocene-Eocene thermal maximum (PETM): Paleocene-Eocene thermal maximum. Geochemistry, Geophysics, Geosystems , 8, https://doi.org/10.1029/2007GC001784

Scheibner, C. and Speijer, R.P. 2008. Decline of coral reefs during Late Paleocene to Early Eocene global Warming. Earth , 3, 19-26, https://doi.org/10.5194/ee-3-19-2008

Scheibner, C., Speijer, R.P. and Marzouk, A.M. 2005. Turnover of larger foraminifera during the Paleocene-Eocene thermal maximum and paleoclimatic control on the evolution of platform ecosystems. Geology , 33, 493, https://doi.org/10.1130/G21237.1

Schmitz, B. and Pujalte, V. 2007. Abrupt increase in seasonal extreme precipitation at the Paleocene-Eocene boundary. Geology , 35, 215-218, https://doi.org/10.1130/G23261A.1

Schmitz, B., Keller, G. and Stenvall, 0. 1992. Stable isotope and foraminiferal changes across the Cretaceous-Tertiary boundary at Stevns Klint, Denmark: arguments for long-term oceanic instability before and after bolide-impact event. Palaeogeography, Palaeoclimatology, Palaeoecology , 96, 233-260, https://doi.org/10.1016/0031-0182(92)90104-D

Schmitz, B., Pujalte, V. et al 2011. The global stratotype sections and points for the bases of the Selandian (Middle Paleocene) and Thanetian (Upper Paleocene) stages at Zumaia, Spain. Episodes , 34, 220-243, https://doi.org/10.18814/epiiugs/2011/v34i4/002

Schulte, P., Alegret, L. et al 2010. The Chicxulub asteroid impact and mass extinction at the Cretaceous-Paleogene boundary. Science , 327, 1214-1218, https://doi.org/10.1126/science.1177265 
Serra-Kiel, J. 1998. Biostratigraphie des macroforaminifères du Paléocène et de l'Eocène de la théthys. Bulletin de la Société géologique de France , 169, 281-299.

Serrano, 0. 2001. Le Crétacé supérieur - Paléogène du bassin compressif nord-Pyrénéen (Bassin de l'Adour). Sédimentologie, stratigraphie, géodynamique. $\mathrm{PhD}$ thesis, Université Rennes 1.

Sluijs, A., Bowen, G.J., Brinkhuis, H., Lourens, L.J. and Thomas, E. 2007. The PalaeoceneEocene thermal maximum super greenhouse: biotic and geochemical signatures, age models and mechanisms of global change. The Micropalaeontological Society, Special Publications, 2, 323-347, https://doi.org/10.1144/TMS002.15

Smith, N.D. 1974. Sedimentology and Bar Formation in the Upper Kicking Horse River, a Braided Outwash Stream. The Journal of Geology , 82, 205-223. https://doi.org/10.1086/627959

Storme, J.-Y. 2013. Organic carbon and nitrogen isotopes of the Palaeocene-early Eocene: implications on stratigraphy, paleoenvironment and paleoclimatology . PhD thesis, University of Namur.

Storme, J.-Y., Devleeschouwer, X. et al 2012. The Paleocene/Eocene boundary section at Zumaia (Basque-Cantabric Basin) revisited: new insights from high-resolution magnetic susceptibility and carbon isotope chemostratigraphy on organic matter ( $\Delta 13$ Corg): the Paleocene/Eocene boundary section. Terra Nova , 24, 310-317, https://doi.org/10.1111/j.1365-3121.2012.01064.x

Storme, J.-Y., Steurbaut, E., Devleeschouwer, X., Dupuis, C., Lacumin, P., Rochez, G. and Yans, J. 2014. Integrated bio-chemostratigraphical correlations and climatic evolution across the Danian-Selandian boundary at low latitudes. Palaeogeography, Palaeoclimatology, Palaeoecology , 414, 212-224, https://doi.org/10.1016/j.palaeo.2014.09.002

Tambareau, Y. 1972. Contribution à l'étude du Thanétien supérieur des Petites Pyrénée . $\mathrm{PhD}$ thesis, University of Toulouse.

Tambareau, Y., Crochet, B., Villatte, J. and Deramond, J. 1995. Evolution tectonosedimentaire du versant nord des Pyrenees centre-orientales au Paleocene et a l'Eocene inferieur. Bulletin de la Société géologique de France , 166, 375-387.

Tambareau, Y., Hottinger, L. et al 1997. Communautes fossiles benthiques aux alentours de la limite Cretace/Tertiaire dans les Pyrenees. Bulletin de la Société géologique de France , 168, 795-804.

Tye, R.S. and Coleman, J.M. 1989. Depositional processes and stratigraphy of fluvially dominated lacustrine deltas: Mississippi delta plain. Journal of Sedimentary Petrology , 59, 973-996.

Vandenberghe, N., Hilgen, F.J. et al 2012. The Paleogene Period. In: F.M. Gradstein, J.G. Ogg, M. Schmitz, G. Ogg, The Geologic Time Scale . Elsevier, 855-921, https://doi.org/10.1016/B978-0-444-59425-9.00028-7

Vergés, J., Fernàndez, M. and Martìnez, A. 2002. The Pyrenean orogen: pre-, syn-, and post-collisional evolution. Journal of the Virtual Explorer , 8, 55-74, https://doi.org/10.3809/jvirtex.2002.00058

Villatte, J. 1962. Etude stratigraphique et paléontologique du Montien des Petites Pyrénées et du Plantaurel. PhD thesis, Toulouse University.

Warwick, P.D. and Ruppert, L.F. 2016. Carbon and oxygen isotopic composition of coal and carbon dioxide derived from laboratory coal combustion: a preliminary study. International Journal of Coal Geology , 166, 128-135, https://doi.org/10.1016/j.coal.2016.06.009 
Watson, D., Schofield, N. et al 2017. Stratigraphic overview of Palaeogene tuffs in the Faroe-Shetland Basin, NE Atlantic margin. Journal of the Geological Society, London , 174, 627-645, https://doi.org/10.1144/jgs2016-132

Westerhold, T., Röhl, U., Donner, B., McCarren, H.K. and Zachos, J.C. 2011. A complete high-resolution Paleocene benthic stable isotope record for the Central Pacific (ODP Site 1209): Paleocene benthic stable isotope record. Paleoceanography , 26, https://doi.org/10.1029/2010PA002092

Williams, G.L., Damassa, S.P., Fensome, R.A. and Guerstein, G. R. 2015. Wetzeliella and its allies - the 'hole' story: a taxonomic revision of the Paleogene dinoflagellate Subfamily Wetzelielloideae. Palynology , 39, 289-344, https://doi.org/10.1080/01916122.2014.993888

Wright, V.P. and Tucker, M.E. 1991. Calcretes: an introduction. Reprint Series 2 of the International Association of Sedimentologists, 1-22.

Wright, V.P., Platt, N.H., Marriott, S.B. and Beck, V.H. 1995. A classification of rhizogenic (root-formed) calcretes, with examples from the Upper Jurassic-Lower Cretaceous of Spain and Upper Cretaceous of southern France - reply. Sedimentary Geology , 110, 305-307. https://doi.org/10.1016/S0037-0738(96)00091-7

Yans, J., Marandat, B. et al 2014. Refined bio- (benthic foraminifera, dinoflagellate cysts) and chemostratigraphy of the earliest Eocene at Albas-le Clot (Corbières, France): implications for mammalian biochronology in southern Europe. Newsletters on Stratigraphy , 47, 331-353, https://doi.org/10.1127/nos/2014/0050

Zachos, J.C. 2001. Trends, rhythms, and aberrations in global climate 65 Ma to Present. Science , 292, 686-693, https://doi.org/10.1126/science.1059412

Zachos, J.C. 2005. Rapid Acidification of the Ocean During the Paleocene-Eocene Thermal Maximum. Science , 308, 1611-1615. https://doi.org/10.1126/science.1109004

Zachos, J.C., Dickens, G.R. and Zeebe, R.E. 2008. An early Cenozoic perspective on greenhouse warming and carbon-cycle dynamics. Nature , 451, 279-283, https://doi.org/10.1038/nature06588

Zhu, C., Wagner, T., Pan, J.-M. and Pancost, R.D. 2011. Multiple sources and extensive degradation of terrestrial sedimentary organic matter across an energetic, wide continental shelf. Geochemistry, Geophysics, Geosytems , 12, https://doi.org/10.1029/2011GC003506 
Table 1. Description of the main lithofacies and depositional environments of the Lairiere section

\section{Description of lithofacies}

Lithofacies 1 (L1): conglomerate. Clast-supported conglomerates with a medium-grained sandy matrix, eventually containing Microcodium debris. Pebble sizes range from 1 to $10 \mathrm{~cm}$. Pebble lithologies are mainly of local Mesozoic carbonates (80\%) and subordinate quartzite and sandstones. Imbrications are occasional and compression marks on pebbles are frequent. The size of the conglomerate beds is between $20 \mathrm{~cm}$ and $2 \mathrm{~m}$; they show erosive bases and are locally intercalated with medium-grained sandstone lenses that show planar and trough-cross-stratification. They form lenticular units up to $5 \mathrm{~m}$ thick with metre- to kilometre-scale lateral extent. Their occurrence in the succession is very low $(<2 \%)$

Lithofacies 2 (L2): fine sandstones. These sandstones contain very well-sorted, very fine to fine grains, with occasional sparse conglomeratic lenses. The grains are mainly quartz. Beds are 3-10 m thick. They occasionally show planar cross-stratification, trough-crossstratification and ripple lamination, but more often there is no lamination due to very good sorting. They form fining-upwards units up to $2 \mathrm{~m}$ thick with erosive bases. Some beds present large lateral accretions with

\section{Interpretation}

L1 are fluvial sediments deposited in erosive channel forms within floodplain deposits (see L3, below). Preserved conglomeratic bedforms (L1) show little indication of imbrication, but cross-stratification is common. However, they are punctuated by smaller cross-bedded sandstone beds, which indicates that deposition occurred within a two-phase turbulent flow (Allen 1985), probably during the waning phase of the flood (Smith 1974; Bluck 1979). By contrast, clast-supported conglomerates, together with the sandy matrix, were deposited during higher flood stages when the stream capacity was higher (Bluck 1979). The clasts come from local sources (Plaziat 1984), probably the Mouthoumet Massif, suggesting that these deposits are characteristic of a short, pebbly fluvial system with a high gradient

L2 are fluvial sediments deposited in erosive channels within the floodplain deposits (see L5, below) Preserved sandstone bodies comprise two groups: (L2a) large bodies showing planar crossstratifications corresponding to the lateral accretion of a fluvial bar within the channel (Díaz-Molina 1993; Martinius 2000); and (L2b) smaller sand bodies showing well-sorted, very fine sandstones within channel forms that pass laterally to tabular channel
Depositional environment Fluvial channel and wings

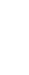


accretion across tens of metres (L2a). These units display either very large channel-form bodies that are erosive and show a lateral extension from 100 to $300 \mathrm{~m}$. Other beds show narrow channel forms not exceeding $50 \mathrm{~m}$ in width (L2b) and $2 \mathrm{~m}$ in thickness (ribbon geometry). These small channel forms are always connected to more tabular, slightly erosive beds (L2c) intercalated in the claystones and siltstones of the floodplain (L5); several of these channel forms lie on the same stratigraphic horizons and their wings are connected. The tops of the sand bodies (L2a, b, c) show mottling, a nodular fabric and root traces; some beds contain Microcodium. These channel and wing deposits represent c. $20 \%$ of the section

Lithofacies 3 (L3): truncating sandstones. Fine to very fine, very well-sorted sandstone showing large bodies ( $>300 \mathrm{~m}$ of lateral extension), slightly erosive, but locally showing a more pronounced channel-like gully. These beds show very few sedimentary structures, but have internal erosion surfaces. These bodies are either the basal unit of the overlying downlapping couplets of sandstones and siltstone lenses (L4 and L5) or the uppermost unit truncating the prograding couplets

Lithofacies 4 (L4): Downlapping heterolithic sandstones. Lenses of fine to very fine sandstones $(>1 \mathrm{~m}$ thick) alternating with yellow to red mottled siltstones showing large accretion (up to $3 \mathrm{~m}$ ). Each couplet of sandstone/siltstone terminates onto a lower planar geological surface (either L3 sandstones or an internal wings (Gibling 2006) representing overbank deposits (L2c). L2a is typical of sinuous channels that meander within the floodplain (Miall 1996). L2b shows less sedimentary structures and therefore the sinuosity cannot be reconstructed with confidence, but these ribbon channels are small and the connections between channels with more tabular wings (L2c) attest to anastomosed systems (Nanson and Croke 1992; Nadon 1994). Most of these sand bodies were affected by pedogenesis with numerous root traces, which suggests that the groundwater levels were relatively high and the development of vegetation was fast relative to channel migration and floodplain sedimentation (Wright et al. 1995)

These relatively structureless beds are interpreted as amalgamated channel fills of a lacustrine delta plain (distributary channels; Pollard et al. 1982; Tye and Coleman 1989) as a result of their geometric relationship with the following lithofacies (L4), which shows progradational features. Well-sorted grains inhibit interpretation of the internal geometries and therefore it is not clear whether these deposits are subaerial or subaqueous (Pollard et al. 1982). The L3 sand bodies lie on low-angle stratigraphic horizons indicating deposition on a low-angle gradient (Rich 1951)

Sandstones interbedded with siltstones showing downlapping and progradational large structures, forming a clinoform architecture (e.g. Rich 1951), indicating deposition on a higher slope than the fluvial gradient. These clinoform geometries are better described and studied in marine settings (e.g. Rich
Lacustrine delta 
stratigraphic surface). The top accretionary unit is truncated by a large L3 sand body

Lithofacies 5 (L5): siltstone and claystone. Fine to very fine, yellow, grey or red in colour, often showing pervasive mottling (L5a). This lithofacies has a high carbonate content, often $>60 \%$. Some beds contain sparse to abundant carbonaceous glaebules and occasionally root traces (L5b); others show coalescent glaebules (L5c), locally presenting a vertical fabric and root traces and evolving locally to pedogenetic carbonate beds

L5c: When glaebules are coalescent, then the palaeosols
1951, Driscoll and Karner 1999; Hampson 2010) than in lacustrine environments (Tye and Coleman 1989). This geometry suggests the termination of detrital fluxes into a standing body of water c. $3 \mathrm{~m}$ in depth. These heterolithic clinoforms correspond to a lacustrine delta front in which rare biological features were found. Siltstones transported in suspension upstream in the river and distributary channels of the delta plain were deposited in the delta front system during phases of low water stage. They were deposited on well-identified underwater slopes (clinoforms), whereas the sandstones were probably deposited during higher flood stages and perhaps by gravity flows. Mottling throughout the siltstones and sandstones probably occurred much later after deposition

L5 consists of floodplain deposits, where the sediments were deposited in low-gradient areas and intercalated between channel-form lenses or overbank deposits (L1 and L2). They were deposited after the maximum flood when the current decreased, allowing the deposition of the finest particles, such as silt and clay (Bridge 2007). The carbonate content and mottling are indicators of pedogenesis and vadose processes. Carbonate cement forms in the vadose zone when the groundwater is high and the sediments are saturated. Mottling forms during the migration of iron. L5b: Sparse to abundant glaebules are characteristic of Ca-rich palaeosols of medium maturity (stages 2 and 3; Bachman and Machette 1977) typical of seasonal contrasts when evaporation is important.

Floodplain 
are more mature (stages 4 and 5; Bachman and Machette 1977) and these beds suggest that soil formation lasted for a longer time (Wright and Tucker 1991)

Lithofacies (L6): Microcodium beds. Dark red Microcodium bed containing coarse Microcodium grains with clay coatings forming irregular beds of 1-10 m thick and of large lateral extent $(100 \mathrm{~m}$ scale). These beds are located close to the channel bodies or form the top of the channel-fill sequences

Lithofacies 7 (L7): grey carbonate mudstone. These mudstones contain occasional charophyta, ostracods and gastropod fragments. They either form tabular extensive beds $2-50 \mathrm{~m}$ thick or beds of limited extension laterally to L5c or L8

Lithofacies 8 (L8): mottled carbonate mudstone. White to pink mottled carbonate mudstone showing desiccation cracks and root traces. They are largely recrystallized. They form roughly tabular beds with irregular tops, often showing a nodular fabric. Beds are $50 \mathrm{~cm}$ to few metres thick and are laterally equivalent to L5 and L6

Lithofacies 9 (L9): rippled sandstones. Yellow to grey organic-rich sandstone containing fine to medium grains. Grains are mainly quartz, milliolids and coal and plant fragments. Beds are centimetre scale with erosive bases.
These beds always located close to the main channels or at the top of the channel fills. As a result of their position relative to the depositional channels, the beds are interpreted as either ancient overbank/levee deposits or final fine-grained channel-fill sequences that were totally transformed by the peculiar pedogenic processes that form Microcodium crystals, invading the host sediments (Freytet and Plaziat 1982; Wright and Tucker 1991; McConnaughey and Whelan 1997), which were probably in a relatively wet environment

Continental carbonates (L4) and swamp or lake-edge sediments (L5). Continental carbonates indicate the large and long-term presence of lakes. These facies may be the edges of these lakes, or seasonal wetlands, reflecting an alternation of wet and dry seasons with strong pedogenetic features (Freytet and Verrecchia 2002; Marty and Meyer 2006)

Undulating erosion surfaces with ripples characterize a wave-dominated environment with a low-energy gradient. The presence of quartz, plant detritus and Microcodium detritus indicate proximity to the
Continental carbonates

Shallow marine 
They show millimetre-scale trough-cross-stratification that form packages up to $2 \mathrm{~m}$ thick overlying a major erosional surface

Lithofacies 10 (L10): mudstone to wackestone. Carbonate beds containing dasyclad green algae, frequent miliolids, alveolinids, rare planktonic forams, ostracods, peloids and mollusc shells, some of which consist of fine quartzitic grains with occasional bioturbation. Beds are $50 \mathrm{~cm}$ to $1 \mathrm{~m}$ in thickness and present a large regional extent

Lithofacies 11 (L11). Packstone to grainstone with abundant oolitic grains in some beds, gastropods, bivalve shells, corals, and the remains of echinoderms, rare miliolids, alveolinids, planktonic foramis, red algae and dasyclad green algae continent. This lithofacies was deposited in a shallow choppy marine environment in a mangrove swamp (Plaziat 1981) with a nearby supply of clastic material L10 is interpreted as a restricted lagoonal facies to an internal facies in a shallow carbonate platform. It is the proximal part of the system (Plaziat 1981, 1984; Flügel 2010; Pomar 2001)

L11 is interpreted as an external lagoonal facies to an internal pararecifal facies on a shallow carbonate platform. It is the distal part of the system (Plaziat 1981, 1984; Flügel 2010; Pomar 2001) 
Supplementary material 1: Carbon isotope $813 \mathrm{Corg}$ values, $\mathrm{TOC}$ and $\mathrm{CaCO} 3$ contents on samples of the studied Lairière section.

\begin{tabular}{|c|c|c|c|c|}
\hline Sample & Metering (m) & CaCO3 (\%) & TOC (\%) & $\delta^{13} C_{\text {org }}( \pm 0.3 \%)$ \\
\hline La-04 0,8 & 0,8 & 81,00 & 0,03 & $-26,3$ \\
\hline La-06 7 & 7,0 & 94,25 & 0,11 & $-28,8$ \\
\hline La-06 7,5 & 7,5 & 94,74 & 0,02 & $-26,6$ \\
\hline La-07 17 & 17,0 & 82,96 & 0,07 & $-24,7$ \\
\hline La-06 19 & 19,0 & 90,26 & 0,01 & $-25,6$ \\
\hline La-06 23 & 23,0 & 91,03 & 0,05 & $-28,8$ \\
\hline La-06 31 & 31,0 & 95,71 & 0,01 & $-25,1$ \\
\hline La-06 37 & 37,0 & 91,46 & 0,03 & $-25,6$ \\
\hline La-06 39 & 39,0 & 98,72 & 0,00 & $-24,7$ \\
\hline La-04 40 & 40,0 & 93,00 & 0,17 & $-24,3$ \\
\hline La-06 42,5 & 42,5 & 99,46 & 0,05 & $-26,2$ \\
\hline La-04 44,5 & 44,5 & 76,00 & 0,05 & $-24,7$ \\
\hline La-04 47,5 & 47,5 & 84,00 & 0,04 & $-23,8$ \\
\hline La-04 49 & 49,0 & 73,00 & 0,05 & $-23,7$ \\
\hline La-04 53 & 53,0 & 99,00 & 0,00 & $-27,5$ \\
\hline La-07 57 & 57,0 & 68,85 & 0,01 & $-25,1$ \\
\hline La-04 60 & 60,0 & 80,00 & 0,03 & $-25,7$ \\
\hline La-07 65,5 & 65,5 & 65,51 & 0,02 & $-25,8$ \\
\hline La-06 67 & 67,0 & 76,43 & 0,04 & $-26,5$ \\
\hline La-07 71,5 & 71,5 & 60,43 & 0,02 & $-25,5$ \\
\hline La-06 79 & 79,0 & 80,36 & 0,03 & $-24,7$ \\
\hline La-04 83,5 & 83,5 & 63,00 & 0,03 & $-25,1$ \\
\hline La-04 89 & 89,0 & 71,00 & 0,03 & $-23,4$ \\
\hline La-04 93,5 & 93,5 & 76,00 & 0,02 & $-25,1$ \\
\hline La-04 99 & 99,0 & 72,00 & 0,03 & $-24,2$ \\
\hline La-04 104 & 104,0 & 64,00 & 0,03 & $-24,1$ \\
\hline La-04 106 & 106,0 & 60,00 & 0,06 & $-24,8$ \\
\hline La-07 111 & 111,0 & 57,11 & 0,03 & $-24,3$ \\
\hline La-06 112,5 & 112,5 & 86,51 & 0,02 & $-24,4$ \\
\hline La-07 114 & 114,0 & 38,82 & 0,03 & $-23,7$ \\
\hline La-07 114,5 & 114,5 & 34,55 & 0,04 & $-23,1$ \\
\hline La-04 118 & 118,0 & 70,00 & 0,06 & $-25,1$ \\
\hline La-04 122 & 122,0 & 77,00 & 0,06 & $-25,5$ \\
\hline La-07 127 & 127,0 & 38,49 & 0,04 & $-22,3$ \\
\hline La-04 131 & 131,0 & 47,00 & 0,07 & $-24,4$ \\
\hline La-07 132 & 132,0 & 41,54 & 0,03 & $-24,7$ \\
\hline $\begin{array}{l}\text { La-07 136,3- } \\
136,5\end{array}$ & 136,4 & 40,62 & 0,04 & $-23,8$ \\
\hline La-07 138 & 138,0 & 56,61 & 0,03 & $-23,5$ \\
\hline La-04 139,5 & 139,5 & 54,00 & 0,07 & $-24,4$ \\
\hline La-04 142 & 142,0 & 36,00 & 0,08 & $-23,9$ \\
\hline La-04 146,5 & 146,5 & 55,00 & 0,05 & $-23,9$ \\
\hline La-06 149 & 149,0 & 47,87 & 0,04 & $-24,4$ \\
\hline La-07 151,5 & 151,5 & 56,68 & 0,03 & $-22,6$ \\
\hline La-04 155 & 155,0 & 55,80 & 0,07 & $-24,4$ \\
\hline La-04 158 & 158,0 & 53,00 & 0,06 & $-24,9$ \\
\hline La-04 158 & 158,0 & 53,00 & 0,07 & $-24,8$ \\
\hline La-04 159 & 159,0 & 46,43 & 0,21 & $-25,4$ \\
\hline La-04 160,5 & 160,5 & 59,00 & 0,07 & $-24,6$ \\
\hline La-04 162,5 & 162,5 & 68,00 & 0,05 & $-24,5$ \\
\hline La-06 168 & 168,0 & 61,29 & 0,03 & $-24,6$ \\
\hline La-04 171 & 171,0 & 69,00 & 0,30 & $-23,8$ \\
\hline
\end{tabular}




\begin{tabular}{|c|c|c|c|c|}
\hline La-04 171 & 171,0 & 69,00 & 0,32 & $-23,9$ \\
\hline La-04 171 bis & 171,0 & 50,00 & 0,23 & $-23,9$ \\
\hline La-04 171,5 & 171,5 & 64,00 & 0,26 & $-20,6$ \\
\hline La-04 172,5 & 172,5 & 82,00 & 0,17 & $-21,9$ \\
\hline La-04 174,5 & 174,5 & 87,00 & 0,10 & $-23,1$ \\
\hline La-06 175 & 175,0 & 97,31 & 0,03 & $-24,2$ \\
\hline La-06 176 & 176,0 & 96,34 & 0,03 & $-26,3$ \\
\hline La-06 176,5 & 176,5 & 49,57 & 0,06 & $-23,5$ \\
\hline La-04 177 & 177,0 & 99,00 & 0,02 & $-25,4$ \\
\hline La-06 183,5 & 183,5 & 99,08 & 0,04 & $-25,4$ \\
\hline La-07 183,5 & 183,5 & 96,48 & 0,07 & $-25,4$ \\
\hline La-04 187 & 187,0 & 99,00 & 0,06 & $-29,1$ \\
\hline La-07 187,5 & 187,5 & 98,82 & 0,03 & $-28,3$ \\
\hline La-04 188,5 & 188,5 & 99,00 & 0,03 & $-27,1$ \\
\hline La-07 188,5 & 188,5 & 97,53 & 0,03 & $-27,3$ \\
\hline bis & & & & \\
\hline $\begin{array}{l}\text { La-07 188,5 } \\
\text { ter }\end{array}$ & 188,5 & 99,11 & 0,03 & $-27,6$ \\
\hline La-06 190 & 190,0 & 45,43 & 0,04 & $-24,0$ \\
\hline La-04 196 & 196,0 & 77,00 & 0,05 & $-21,7$ \\
\hline La-04 201,5 & 201,5 & 71,00 & 0,04 & $-23,5$ \\
\hline La-06 205 & 205,0 & 50,97 & 0,04 & $-24,2$ \\
\hline La-06 211,5 & 211,5 & 80,76 & 0,03 & $-25,1$ \\
\hline La-04 217 & 217,0 & 67,00 & 0,07 & $-25,2$ \\
\hline La-07 222,5 & 222,5 & 40,34 & 0,03 & $-22,3$ \\
\hline La-04 225,5 & 225,5 & 97,00 & 0,04 & $-24,5$ \\
\hline La-04 230 & 230,0 & 66,00 & 0,05 & $-23,5$ \\
\hline La-04 236 & 236,0 & 68,00 & 0,03 & $-24,3$ \\
\hline La-04 246 & 246,0 & 63,00 & 0,05 & $-23,7$ \\
\hline La-07 251 & 251,0 & 67,48 & 0,04 & $-21,6$ \\
\hline La-07 257 & 257,0 & 61,89 & 0,02 & $-22,9$ \\
\hline La-04 263 & 263,0 & 68,00 & 0,05 & $-23,4$ \\
\hline La-06 266 & 266,0 & 86,05 & 0,03 & $-24,0$ \\
\hline La-06 268 & 268,0 & 79,37 & 0,03 & $-24,6$ \\
\hline La-04 269,5 & 269,5 & 66,00 & 0,04 & $-23,7$ \\
\hline La-07 271,5 & 271,5 & 52,44 & 0,02 & $-23,5$ \\
\hline La-07 273,6 & 273,6 & 45,90 & 0,03 & $-23,7$ \\
\hline La-07 275 & 275,0 & 52,84 & 0,02 & $-23,8$ \\
\hline La-07 276 & 276,0 & 83,54 & 0,05 & $-24,7$ \\
\hline La-04 283 & 283,0 & 67,00 & 0,03 & $-23,3$ \\
\hline La-04 290 & 290,0 & 72,00 & 0,03 & $-23,4$ \\
\hline La-07 297 & 297,0 & 60,64 & 0,03 & $-23,8$ \\
\hline La-04 299 & 299,0 & 81,00 & 0,03 & $-23,6$ \\
\hline La-06 302 & 302,0 & 71,05 & 0,06 & $-25,8$ \\
\hline La-04 309 & 309,0 & 78,00 & 0,04 & $-24,3$ \\
\hline La-04 309,5 & 309,5 & 76,00 & 0,05 & $-23,3$ \\
\hline La-07 326,5 & 326,5 & 84,44 & 0,04 & $-22,7$ \\
\hline La-07 329 & 329,0 & 59,62 & 0,02 & $-23,5$ \\
\hline La-04 337A & 337,0 & 79,00 & 0,04 & $-24,4$ \\
\hline La-04 337B & 337,0 & 68,00 & 0,05 & $-23,5$ \\
\hline La-04 338,5 & 338,5 & 83,00 & 0,04 & $-23,7$ \\
\hline La-04 340 & 340,0 & 62,00 & 0,12 & $-23,7$ \\
\hline La-04 343 & 343,0 & 74,00 & 0,07 & $-24,4$ \\
\hline La-07 346 & 346,0 & 58,94 & 0,05 & $-23,4$ \\
\hline
\end{tabular}




\begin{tabular}{lcccc} 
La-07 353 & 353,0 & 52,96 & 0,04 & $-24,4$ \\
La-04 354,5 & 354,5 & 76,00 & 0,09 & $-24,5$ \\
La-04 359 & 359,0 & 96,00 & 0,08 & $-25,0$ \\
La-04 376,5 & 376,5 & 96,00 & 0,01 & $-22,5$ \\
La-04 377 & 377,0 & 96,00 & 0,03 & $-25,4$ \\
La-04 378,5 & 378,5 & 99,00 & 0,03 & $-25,1$ \\
La-04 382 & 382,0 & 74,00 & 0,05 & $-23,4$ \\
La-04 386,5 & 386,5 & 64,00 & 0,06 & $-23,9$ \\
La-04 409 & 409,0 & 52 & 0,04 & $-26,2$ \\
La-04 421 & 421,0 & 34,00 & 0,06 & $-25,8$ \\
La-07 425 & 425,0 & 42,97 & 0,04 & $-23,1$ \\
La-07 429 & 429,0 & 39,59 & 0,04 & $-23,0$ \\
La-07 433 & 433,0 & 35,31 & 0,03 & $-23,0$ \\
La-04 434 & 434,0 & 49,00 & 0,06 & $-23,7$ \\
La-04 438 & 438,0 & 43,00 & 0,06 & $-23,3$ \\
La-04 444 & 444,0 & 46 & 0,05 & $-23,7$ \\
La-04 447 & 447,0 & 48 & 0,04 & $-23,6$ \\
La-04 458 & 458,0 & 77,00 & 0,10 & $-23,7$ \\
La-04 459 & 459,0 & 95,00 & 0,01 & $-23,8$ \\
La-04 466 & 466,0 & 99,00 & 0,01 & $-23,6$ \\
La-04 466,7 & 466,7 & 73,00 & 0,06 & $-23,7$ \\
La-07 470 & 470,0 & 94,77 & 0,09 & $-23,8$ \\
La-07 476 & 476,0 & 95,17 & 0,07 & $-24,6$ \\
\hline
\end{tabular}




\section{Supplementary material 2. Paleomagnetic results}
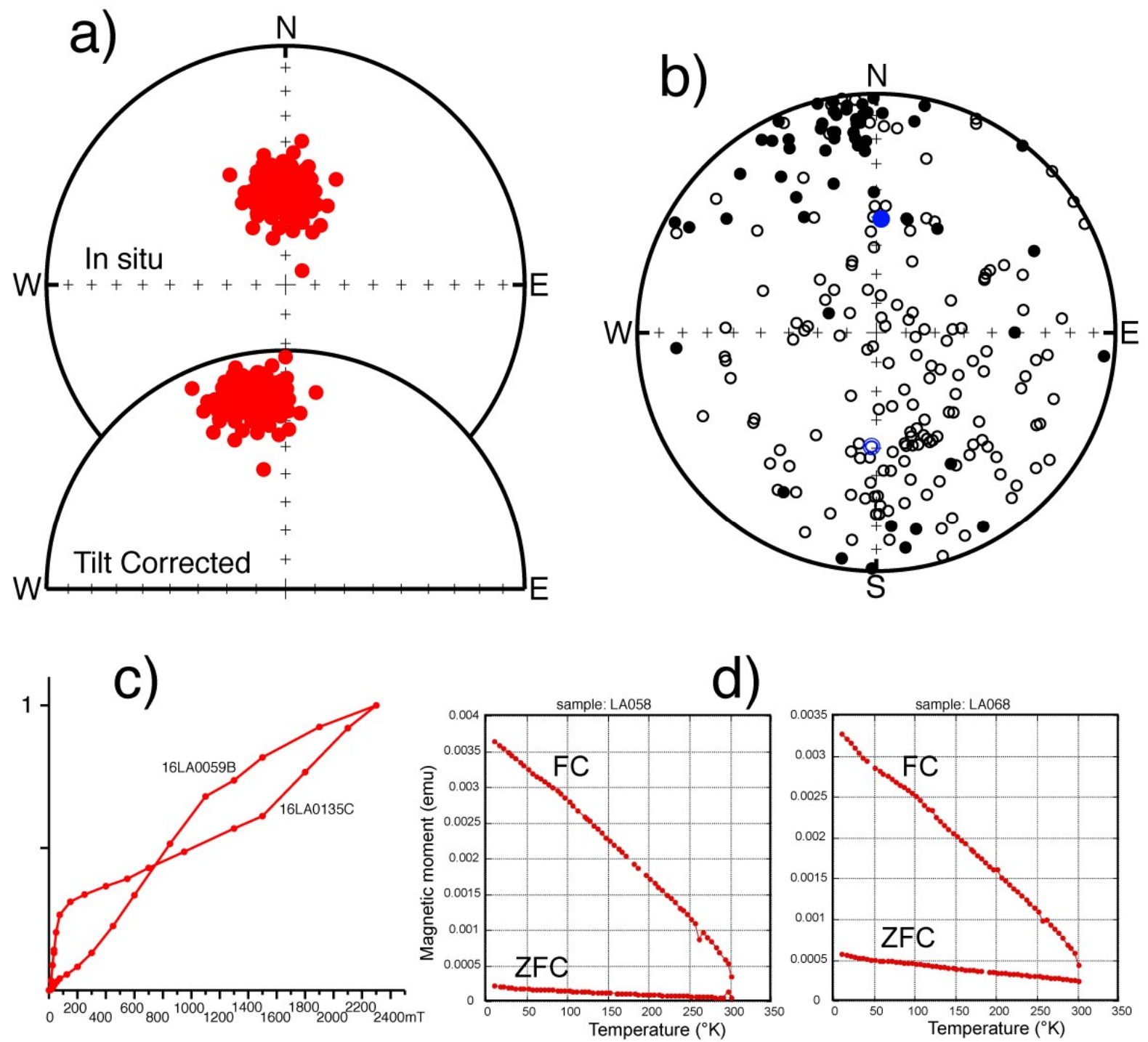

Supplementary Figure A.

a) Equal-area projections of the low temperature component of magnetization determined in the temperature range $80^{\circ}-210^{\circ} \mathrm{C}$ in in situ and after tilt corrected direction. b) Paleomagnetic directions observed in samples demagnetized at $210^{\circ} \mathrm{C}$, shown after tilt correction. Most samples have negative inclinations. Directions of magnetizations with positive inclination correspond mostly to present-day field directions not removed at $210^{\circ} \mathrm{C}$. c) Acquisition of isothermal remanent magnetization showing the presence of high coercivity minerals like goethite and/or hematite. Magnetite is also identified in sample 16LA0135C. d) Examples of low-temperature magnetic measurements showing the large difference between the zero-field (ZFC) and field cooled (FC) experiments. 


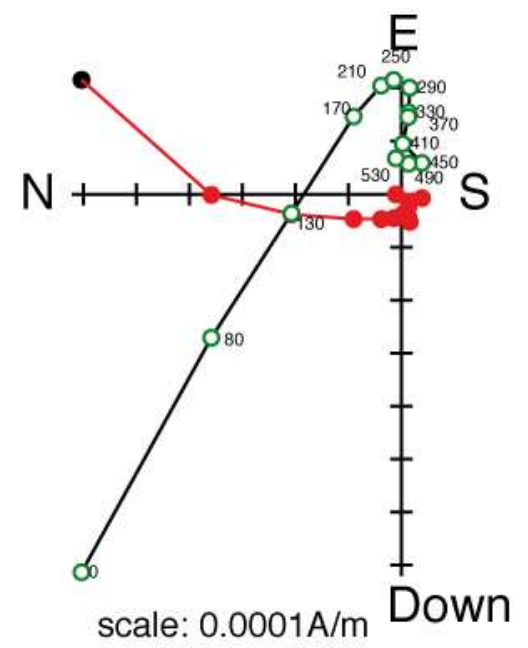

16LA0031A

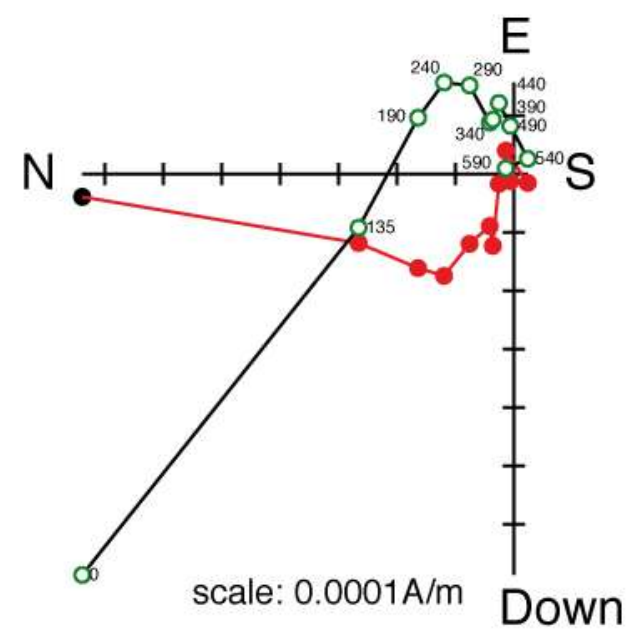

16LA0059A
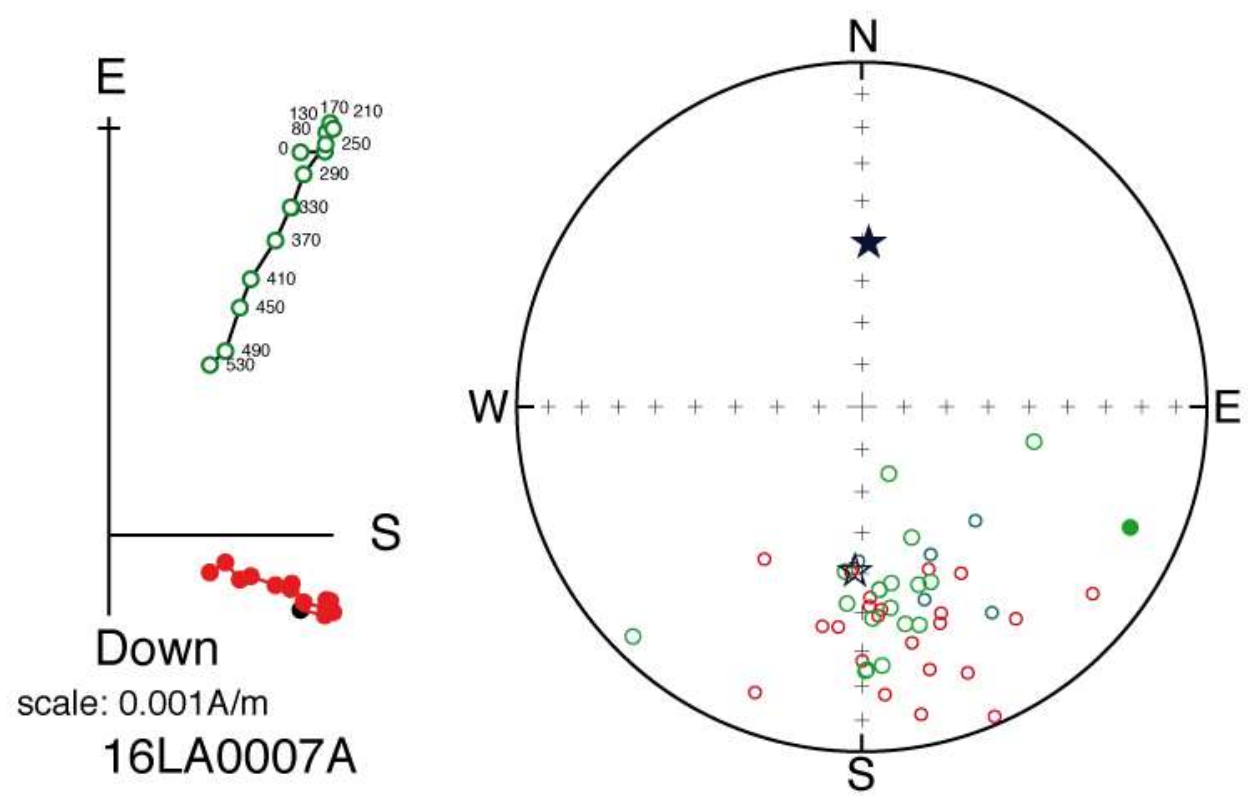

Supplementary Figure B.

Examples of orthogonal plots of thermal demagnetization data in in situ coordinates. Red and green circles correspond respectively to the projection in the horizontal and vertical planes. Samples 16LA0031A and 16LA0059A have a strong overprint in the present-day field while sample 16LA0007A has a very stable magnetization of reverse polarity. Equal area plot of the characteristic remanent magnetizations (ChRM) determined in the sections in tilt-corrected coordinates. Green circles correspond to ChRMs determined by vectors anchored to the origin. Blue circles correspond to ChRMs determined by vectors not anchored to the origin and red circles correspond to directions determined by Fisher statistics on the demagnetization data. Open (filled) symbols correspond to negative (positive) inclination. 
- Line not anchored

- Line anchored

- Fisher mean

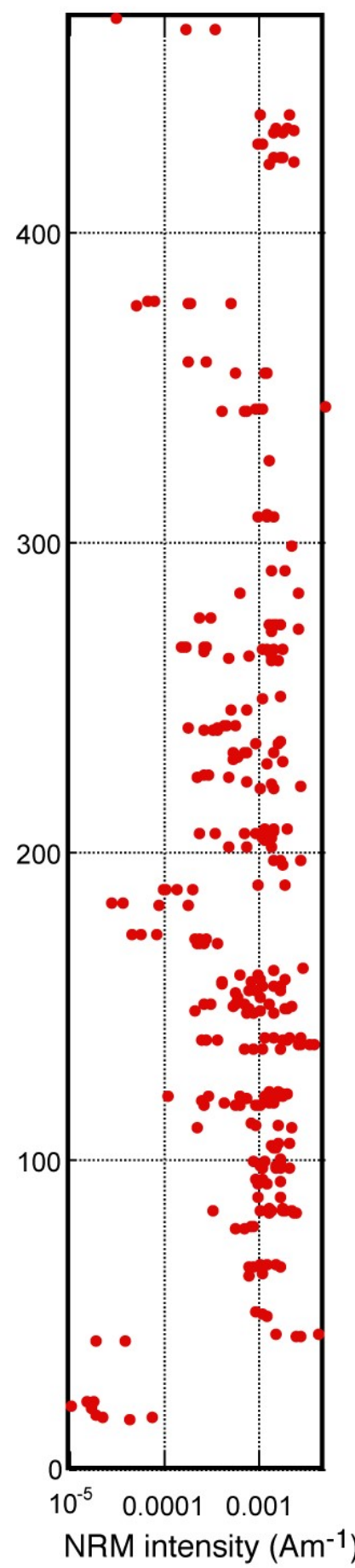

Supplementary Figure C.

left) plot of the intensity of the natural remanent magnetization. right) plot of the reversal angle of samples for which a polarity can be assigned. The reversal angle is the angle between the characterisc magnetization and the expected direction for stable Europe at $60 \mathrm{Ma}$. ( 0 for normal polarity, 180 for reverse polarity) 
Supplementary material 3: type: $\mathrm{f}=$ Fisher statistic on the $\mathrm{N}$ directions measured in the temperature interval Tmin-Tmax. $\neg \mathrm{L} O=$ vector anchored to the origin; $L=$ vector not anchored to the origin; DI-IS and DI-TC are the $\neg$ characteristic directions in in situ or tilt corrected coordinates; mad is the maximum angle deviation for the vector determination or the semi-angle of confidence for the Fisher statistics. VGP is the the virtual geomagnetic pole calculated from the tilt corrected direction. Reversal angle is the angle between the observed diretion and the expected characteristic direction at 60Ma for $\neg$ Eurasia (apparent polar wander path from Torsvik et al., 2012)

\begin{tabular}{|c|c|c|c|c|c|c|c|c|c|c|c|c|c|}
\hline sample & Height & type & $\mathrm{N}$ & Tmin & $\operatorname{Tmax}$ & & I - IS) & & {$[-\mathrm{TC})$} & mad & VGP & lat/lon & Reversal Angle \\
\hline 16LA0268A & 42.30 & $f$ & 6 & 210 & 410 & 211.6 & -75.4 & 174.5 & -40.6 & 4.9 & -69.7 & 17.1 & ־168.6 \\
\hline 16LA0001A & 43.50 & L o & 5 & 330 & 450 & 232.7 & -70.9 & 184.3 & -42.3 & 2.5 & -71.1 & 350.3 & ר171.6 \\
\hline 16 LA $0002 \mathrm{~A}$ & 43.90 & L o & 5 & 330 & 490 & 212.0 & -72.5 & 177.1 & -38.5 & 5.8 & -68.5 & 9.8 & ־167.3 \\
\hline 16LA0006A & 50.50 & L o & 7 & 290 & 530 & 191.8 & -62.1 & 175.5 & -25.7 & 0.7 & -60.3 & 11.4 & ר64.6 \\
\hline 16LA0007A & 50.90 & L o & 8 & 290 & 530 & 197.0 & -59.6 & 179.2 & -24.4 & 1.3 & -59.8 & 4.1 & ר153.7 \\
\hline 16LA0008A & 51.50 & Lo & 7 & 290 & 530 & 196.8 & -60.0 & 178.9 & -24.8 & 0.8 & -60.0 & 4.7 & ר154.0 \\
\hline 16LA0010A & 64.00 & L o & 3 & 450 & 530 & 115.0 & -12.7 & 114.2 & 15.8 & 3.6 & -11.6 & 69.7 & ᄀ91.0 \\
\hline 16LA0011A & 66.00 & L o & 3 & 450 & 530 & 234.2 & -20.5 & 224.9 & -6.7 & 5.1 & -33.9 & 304.5 & ־123.7 \\
\hline 16LA0020A & 79.25 & $f$ & 7 & 290 & 530 & 215.6 & -39.3 & 200.5 & -12.6 & 7.0 & -49.1 & 330.3 & -139.2 \\
\hline 16LA0031A & 89.00 & $f$ & 5 & 250 & 410 & 261.0 & -75.1 & 183.1 & -51.3 & 5.6 & -78.7 & 348.8 & ר179.1 \\
\hline 16LA0045A & 100.10 & L o & 6 & 330 & 530 & 229.4 & -78.8 & 174.5 & -45.8 & 3.0 & -73.6 & 20.0 & ᄀ172.9 \\
\hline 16LA0056A & 112.40 & L o & 6 & 330 & 530 & -19.7 & -67.7 & 158.0 & -73.0 & 11.9 & -69.4 & 148.7 & ר155.3 \\
\hline 16LA0064A & 120.00 & $f$ & 3 & 240 & 340 & 227.1 & -63.2 & 190.2 & -35.6 & 10.2 & -65.2 & 339.1 & ᄀ164.0 \\
\hline 16LA0067A & 121.00 & L o & 6 & 340 & 590 & 226.8 & -81.7 & 170.5 & -47.0 & 6.1 & -73.3 & 32.8 & ᄀ171.4 \\
\hline 16LA0079A & 137.90 & $\mathrm{~L}$ & 4 & 290 & 410 & 268.1 & -76.3 & 181.3 & -53.1 & 7.0 & -80.6 & 356.1 & ־177.4 \\
\hline 16LA0080A & 138.00 & L & 5 & 290 & 450 & 60.6 & -87.3 & 155.0 & -51.0 & 11.0 & -67.3 & 71.0 & ר162.8 \\
\hline 16LA0082A & 139.50 & $f$ & 5 & 210 & 370 & 257.2 & -74.5 & 183.7 & -50.3 & 12.1 & -77.7 & 347.5 & 179.1 \\
\hline 16LA0086A & 140.20 & $f$ & 4 & 170 & 290 & 263.6 & -55.2 & 212.6 & -46.5 & 4.9 & -59.6 & 291.8 & ־159.7 \\
\hline 16LA0092A & 148.70 & $f$ & 6 & 210 & 410 & 221.1 & -74.4 & 177.8 & -41.7 & 5.9 & -70.9 & 8.7 & ᄀ170.5 \\
\hline 16LA0093A & 149.00 & L o & 5 & 370 & 530 & 228.9 & -78.7 & 174.5 & -45.7 & 7.6 & -73.5 & 19.9 & רי172.8 \\
\hline 16LA0095A & 149.60 & $f$ & 6 & 210 & 410 & 174.0 & -48.6 & 169.1 & -10.1 & 14.5 & -50.9 & 19.9 & ᄀ138.0 \\
\hline 16LA0097A & 150.40 & $f$ & 4 & 210 & 330 & 186.3 & -54.3 & 175.4 & -17.4 & 12.2 & -55.6 & 10.5 & רי3.146. \\
\hline 16LA0107A & 155.30 & $f$ & 4 & 210 & 330 & 114.0 & -46.8 & 129.0 & -15.0 & 8.2 & -33.2 & 69.4 & ᄀ124.5 \\
\hline 16LA0117A & 162.50 & L & 7 & 290 & 530 & 56.7 & -74.9 & 135.1 & -51.5 & 8.7 & -53.3 & 90.6 & ריס150.8 \\
\hline 16LA0118A & 163.00 & L & 7 & 290 & 530 & 171.3 & -80.0 & 162.0 & -40.9 & 7.4 & -65.4 & 45.4 & ᄀ162.9 \\
\hline 16LA0119A & 170.50 & $f$ & 5 & 210 & 330 & 210.0 & -73.8 & 175.5 & -39.1 & 12.3 & -68.8 & 14.1 & ־167.5 \\
\hline 16LA0121A & 171.00 & L & 6 & 290 & 490 & 132.0 & -67.6 & 147.7 & -30.1 & 14.8 & -51.6 & 58.2 & ר147.0 \\
\hline 16LA0156A & 183.60 & $f$ & 5 & 210 & 370 & 155.9 & -41.9 & 156.8 & -2.6 & 6.7 & -43.4 & 35.4 & ר127.4 \\
\hline 16LA0164A & 196.50 & $f$ & 5 & 210 & 370 & 161.7 & -73.0 & 160.1 & -33.7 & 10.4 & -60.3 & 43.0 & ר156.6 \\
\hline 16LA0167A & 197.50 & Lo & 4 & 290 & 410 & 50.5 & -53.1 & 101.4 & -47.8 & 3.6 & -27.1 & 107.8 & ־129.7 \\
\hline 16LA0179A & 207.00 & $f$ & 4 & 210 & 330 & 158.3 & -75.4 & 159.0 & -36.1 & 11.3 & -61.0 & 46.6 & 157.8 \\
\hline 16LA0134A & 224.70 & L o & 5 & 290 & 450 & 176.7 & -73.7 & 165.2 & -34.9 & 6.9 & -63.2 & 34.8 & ר.000 \\
\hline 16LA0135A & 224.90 & L o & 5 & 290 & 450 & 180.3 & -84.0 & 162.3 & -45.0 & 6.1 & -68.2 & 49.4 & ־165.5 \\
\hline 16LA0137A & 229.30 & $f$ & 5 & 210 & 370 & 222.2 & -65.8 & 186.1 & -36.0 & 12.0 & -66.4 & 348.1 & $165.2 \neg$ \\
\hline 16LA0150A & 240.30 & $f$ & 5 & 210 & 370 & 180.5 & -69.0 & 168.0 & -30.7 & 9.7 & -61.6 & 27.4 & ר157.4 \\
\hline 16LA0152A & 241.00 & $f$ & 5 & 210 & 370 & 227.3 & -76.0 & 177.5 & -43.9 & 5.9 & -72.6 & 10.1 & ᄀ172.5 \\
\hline 16LA0153B & 241.00 & $f$ & 5 & 210 & 370 & 157.6 & -57.4 & 158.3 & -18.1 & 8.7 & -51.3 & 38.1 & $142.2 \neg$ \\
\hline 16LA0185A & 246.00 & $f$ & 5 & 210 & 370 & 129.0 & -61.7 & 144.0 & -25.0 & 10.6 & -47.0 & 59.5 & ר־141.0 \\
\hline 16LA0195A & 265.30 & L o & 6 & 290 & 490 & 205.5 & -76.8 & 171.9 & -40.8 & 7.5 & -69.2 & 23.8 & רי167.8 \\
\hline 16LA0197A & 265.50 & Lo & 7 & 290 & 530 & -19.8 & -84.0 & 159.1 & -56.7 & 6.8 & -73.1 & 79.7 & ־165.0 \\
\hline 16LA0198A & 265.50 & L o & 7 & 290 & 530 & 153.9 & -83.9 & 158.5 & -44.6 & 2.1 & -65.8 & 55.7 & ר162.9 \\
\hline 16LA0223A & 342.80 & $f$ & 5 & 210 & 370 & 113.1 & -79.8 & 149.2 & -43.2 & 14.4 & -59.1 & 67.1 & ᄀ156.3 \\
\hline 16LA0234A & 377.80 & Lo & 6 & 290 & 490 & 187.7 & -73.8 & 168.7 & -36.0 & 7.3 & -65.1 & 28.3 & ר4162.4 \\
\hline 16LA0235A & 377.90 & $f$ & 5 & 210 & 370 & 138.0 & -86.9 & 157.6 & -47.8 & 14.0 & -67.1 & 61.6 & ר163.6 \\
\hline 16LA0237A & 378.40 & Lo & 6 & 290 & 490 & 258.2 & -73.2 & 185.8 & -50.3 & 7.6 & -77.1 & 339.5 & י177.8 \\
\hline 16LA0238A & 423.00 & $f$ & 4 & 210 & 330 & 171.3 & -61.3 & 165.5 & -22.4 & 10.0 & -56.2 & 28.7 & ר148.8 \\
\hline 16LA0253A & 466.00 & $f$ & 5 & 210 & 370 & 200.7 & -61.8 & 179.9 & -27.2 & 8.4 & -61.4 & 2.8 & ᄀ156.5 \\
\hline
\end{tabular}




\section{Raw palynoflora data from five samples LA171.0m to LA177.5m.}

171.0m - 171.3m: Assemblages oxidised insitu floodplain, kerogen dominated by intertinite. $173.5 \mathrm{~m}$ Intertinite dominates the kerogen, but pollen and some dinocysts are present indicating transition to a marine environment.

$174.5 \mathrm{~m}$ Shelf marine microplankton, dinocyst assemblage dominated by Glaphyrocysta

species and $P$ indentata which occur commonly in higher nutrient input, turbid water masses.

177.5m: low frequencies of chlorophycean algae and acritarchs indicate freshwater to brackish

facies. The abundance of fungal hyphae is characteristic of lacustrine palynofloras derived from floodplains.

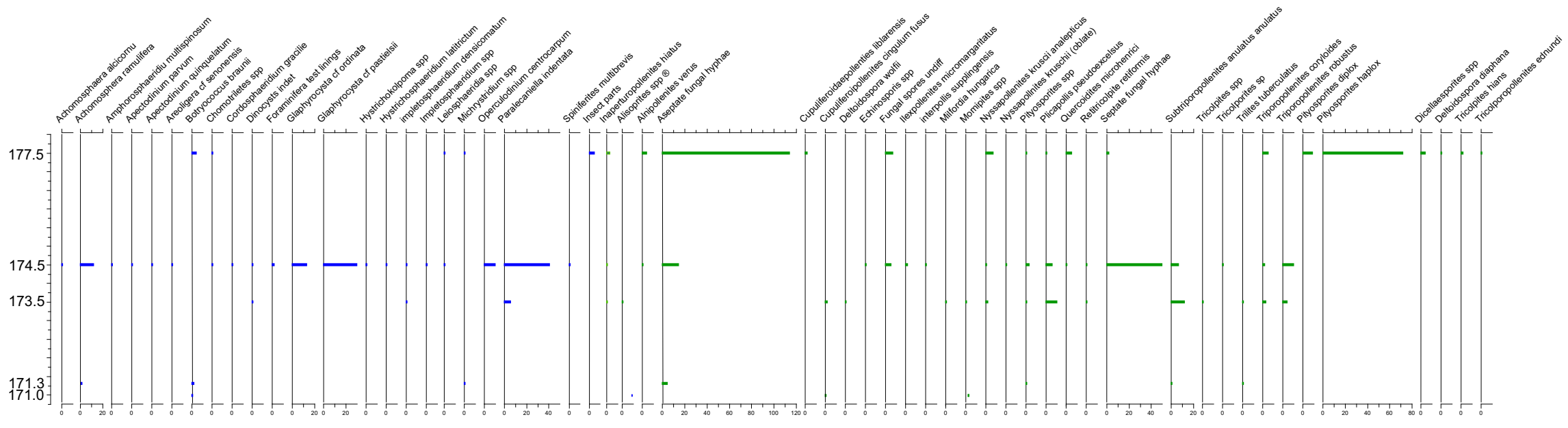

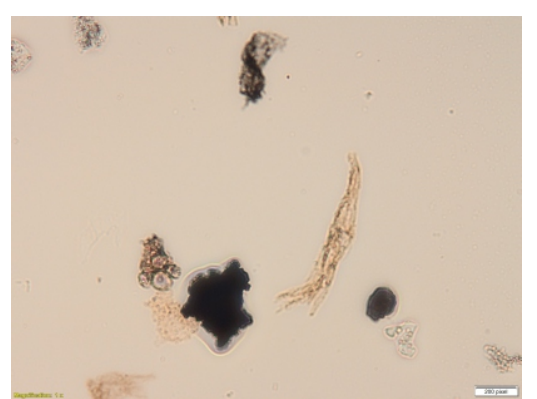

$171.0 \mathrm{~m}$

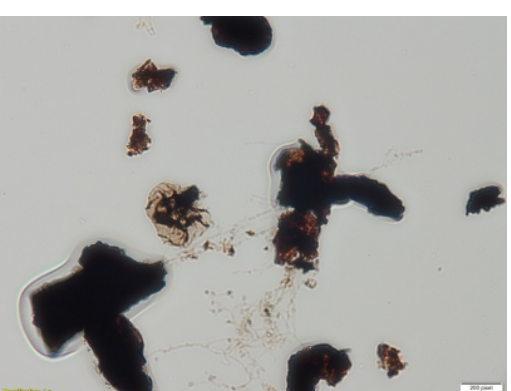

$171.3 \mathrm{~m}$

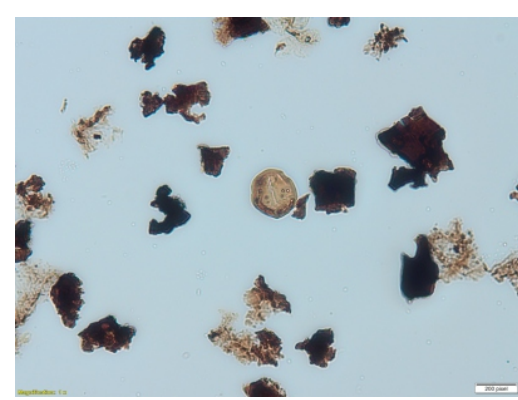

$173.5 m$

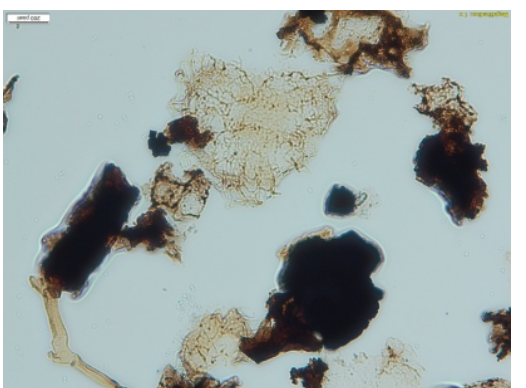

$174.5 \mathrm{~m}$

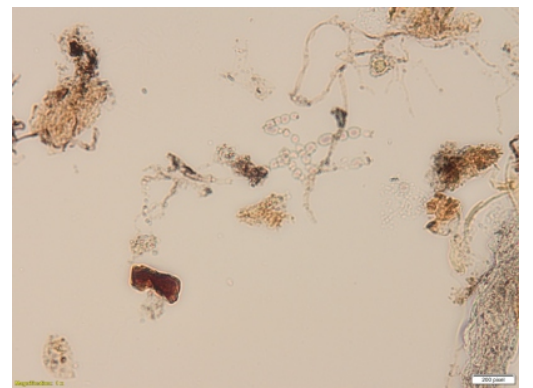

$177.5 \mathrm{~m}$ 